\title{
Science and Philosophy in The Classical Period of Kalām: An Analysis centered upon The Daqiq and Latiif Matters of Kalām
}

Klasik Dönem Kelâmında Bilim ve Felsefe: Kelâmın Dakîk ve Latîf Konuları Ekseninde Bir Değerlendirme

\section{Mehmet BULGEN}

Associate Professor, Marmara University, Faculty of Theology, İstanbul/ Türkiye mbulgen@hotmail.com | orcid.org/0000-0002-2372-471X | ror.org/02kswqa67

\author{
Article Information \\ Article Type \\ Translation \\ Date Recieved \\ 31 October 2021 \\ Date Accepted \\ 31 December 2021 \\ Date Published \\ 31 December 2021 \\ Plagiarism
}

This article has been scanned with iTenticate

software. No plagiarism detected.

\section{Ethical Statement}

It is declared that scientific and ethical principles have been followed while carrying out and writing this study and that all the sources used have been properly cited (Mehmet Bulgen).

Licensed under CC BY-NC-ND 4.0 license.

Cite As

c6 Bulgen, Mehmet. "Science and Philosophy in The Classical Period of Kalām: An Analysis centered upon The Daqiq and Latîif Matters of Kalām". trans. Mehmet Bulgen. Kader 19/3 (December 2021), 938-967. \ https://doi.org/10.18317/kaderdergi.1017086 


\begin{abstract}
One of the important aspects of the classical kalām is that the philosophical topics related to physics and cosmology, namely daqiq or latifif al-kaläm, have an important place in it. The reason for the involvement of the kaläm scholars (mutakallimūn) in these kinds of issues is commonly regarded as an effort to defend Islamic beliefs against other religions and thought systems. However, when their studies are examined closely, the complexity of their concepts and theories, as well as the fact that they discussed these matters not only with opposing groups but also among themselves, show that kaläm had a much deeper and integrated relationship with science and philosophy in the classical period. Their engagement with philosophical and scientific matters, such body (jism), substance/atom (jawhar), accident ('arad), motion, space, time, and causality dates back to the mid- $8^{\text {th }}$ century and displays great diversity. Although the mutakallimūn probably were the first ones to deal with physics-related issues in Islamic thought, it cannot be said that they are given the importance they deserve in modern studies pertaining to the history of science and philosophy in Islamic thought. The fact that, in kalām works, physics-related questions were generally discussed along with theological matters has caused the scholarship of mutakallimūn to be regarded as an adjunct of apologetic discipline and has thereby led to a limited description of kalām's relationship with science and philosophy in the classical period. This set of circumstances hinders a proper understanding of how science and philosophy emerged and evolved in Islamic thought. In the present article, I will attempt to present the place and role of physical topics, namely daqiq or latiif al-kalām, in classical kalām, between the $9^{\text {th }}$ and $11^{\text {th }}$ centuries. Firstly, I will show how the classical mutakallimūn divided kalām into two parts, namely 'major' (jalil) matters, which are based on revelation, and 'subtle' (daqiq) or 'obscure' (latîf) matters, which mainly depend on reason. Matters surrounding jalil al-kalām indicate the theological problems on which the mutakallimūn had a general agreement, such as God's oneness, revelation, prophethood, and eschatology. Questions discussed under the category of daqiq or latif al-kalām mostly correspond to philosophical and scientific issues concerning epistemology, physics, and cosmology. Secondly, I will examine to what extent the mutakallimūn dealt with physical sciences and what kind of topics were primarily discussed in the field of daqiq or latifi al-kaläm. The upshot of this will be that the claim that the mutakallimūn were interested in physics and cosmology merely for apologetic purposes is unsound; rather, in the $9^{\text {th }}$ and $10^{\text {th }}$ centuries, many Muslim theologians also concerned themselves with issues such as motion, void, body, atom, and causality as truth seekers. That being the case, the mutakallimūn should be taken into consideration in studies related to the emergence and rise of science and philosophy in Islamic thought.
\end{abstract}

Keywords: Kalām, Daqī al-kalām, Latîif al-kalām, Jalì al-kalām, Cosmology, Atomism.

\title{
Öz
}

Klasik dönem (mütekaddimûn) kelâmının dikkat çekici özelliklerinden biri "dakîku'l-kelâm” ya da "latîfu'l-kelâm" diye isimlendirilen fizik ve kozmolojiye dair felsefî konuların önemli bir yer tutmasıdır. Kelâmcıların fiziğe dair konulara ilgi duymaya başlama sebebi, İslâm dininin itikadî esaslarını diğer din ve düşünce sistemlerine karşı savunma ihtiyacı şeklinde açıklanmaktadır. Hâlbuki onların çalışmalarına yakından bakıldığında, kelâmcıların kullandıkları kavram ve teorilerin gelişmişliği, ayrıca bu türden konuları sadece karşıt düşünce gruplarıyla değil, birbirleriyle de tartışmaları, klasik dönemde kelâm ilminin bilim ve felsefe ile çok daha derin ve entegrasyona dayalı bir ilişki yaşadığını göstermektedir. Kelamcıların cisim, cevher, araz, hareket, uzay, zaman, nedensellik gibi felsefi ve bilimsel konularla meşgul olmaya başlamaları 2./8. yüzyılın ortalarına kadar uzanmakta ve oldukça zengin bir karakter arz etmektedir. Kelamcılar İslam düşüncesinde muhtemelen fiziğe dair konularla ilk defa uğraşan grup olmakla birlikte İslam bilim ve felsefe tarihi araştırmalarında kendilerine hak ettikleri önemin verildiği söylenemez. Kelâm kitaplarında fiziğe dair konuların genelde teolojik meselelerle birlikte ele alınması onların çalışmalarının daha çok apolojetik bir görünüm kazanmasına ve kelâm ilminin klasik dönemde bilim ve felsefeyle ilişkisinin sınırlı bir şekilde tasvir edilmesine neden olmaktadır. Bu durum İslam düşüncesinde bilimlerin erken dönemden itibaren nasıl ortaya çıkıp gelişim gösterdiğinin gerçekte olduğu gibi anlaşılmasına engel olmaktadır. Bu makale, klasik dönemde "dakîku'l-kelâm" diye isimlendirilen fizik ve kozmolojiye dair konuların kelâmda ne tür bir yeri ve rolü olduğunu ortaya koymayı amaçlamaktadır. Bu bağlamda birinci bölümde klasik dönemde kelâm ilminin vahye dayalı "celîlü'l-kelâm" ile akla dayalı tartışmaları ihtiva eden "dakîkü'l-kelâm" olmak üzere iki temel kısma ayrıldığı ortaya konulacaktır. Bu ayrımda celil konular kelamcıların genel olarak üzerinde uzlaştıkları Allah'ın birliği, vahiy, nübüvvet ve ahiret inancı gibi teolojik konulara tekabül ederken, dakîk ya da latif başlıkları altında ele alınan konular ise daha çok fizik ve kozmolojiye dair felsefi ve bilimsel konulara karşllık gelmektedir. íkinci bölümde kelâmcıların fizik ve kozmolojiye dair konularla hangi ölçekte meşgul oldukları ve dakîku'l-kelâm başlığı altında daha çok ne tür meseleleri ele aldıkları konusu ele alınacaktır. Nihai olarak kelamcıların fizik ve kozmoloji meseleleriyle salt 
apolojetik amaçlarla ilgilendiği iddiasının temelsiz olduğu; aksine 9. ve 10. yüzyıllarda birçok kelamcının hareket, boşluk, cisim ve nedensellik gibi konularla birer hakikat arayıcı olarak ilgilendikleri sonucuna ulaştım. Bu yüzden kelamcıların, İslam düşüncesinde bilim ve felsefenin ortaya çıkış ve gelişimine ilişkin çalışmalarda daha fazla yer bulmaları gerekmektedir.

Anahtar Kelimeler: Kelâm, Dakîku'l-kelâm, Latîfu'l-kelâm, Celîlü'l-kelâm, Kozmoloji, Atomculuk.

\section{Introduction}

One of the remarkable characteristics of the science of kaläm, which was founded by Mu'tazili theologians in the early $8^{\text {th }}$ century, is that its scholars (mutakallimūn) not merely engaged in theological matters, but also in matters falling within the scope of science and philosophy. When their studies are examined closely, it is seen that they intensively discussed issues on the definition of knowledge, the classification of existing things, the structure of matter, properties of bodies, the nature of space, time, motion, and the problem of causation in addition to matters concerning God's existence, His oneness, His attributes, revelation, and prophethood. ${ }^{1}$

It is surprising that the mutakallimūn in the classical period of kaläm actually dealt with questions pertaining to science and philosophy aside from dealing with determining, demonstrating, and defending Islam's revelation-based principles. This raises questions regarding kalām's true nature and what kind of relationship it has built with science and philosophy. In fact, the discussions present in kaläm books about such issues as knowledge (ilm), existent (mawjūd), nonexistence (madūm), substance (jawhar), accident ('araḍ), atom (al-juz' alladhì lā yatajazza'), void (khalā'), motion, space, time and causality are usually handled in an intertwined manner with theological matters. The mutakallimūn used these philosophical concepts and theories to expound on theological quesitons. This causes most of the researchers come to the conclusion that the mutakallimūn did not deal with the philosophical questions related to physics and cosmology as seekers of truth, but with the purpose of defending Islam's revelation-based principles (apologetically) or demonstrating these core principles based on reason instead. However, looking closely at their works, it is easily noticeable that the mutakallimün coined original concepts and developed sophisticated theories about knowledge, existence, and the universe. Besides, they discussed these matters not only with proponents of opposing thought systems but also among themselves, and penned books dedicated to explicating certain questions of physics and cosmology. This has rendered the limited and superficial framework depicting kalām's association with natural sciences insufficient and brought up the idea of a more comprehensive and integrative relation.

The fact that physics-related matters are studied together with theological matters in the kaläm books has created confusion among researchers who have attempted to describe kaläm's relationship with science and philosophy. Therefore, while some researchers have described this

The fact that mutakallimūn dealt with philosophical and scientific issues about the universe in addition to theological issues is also reflected in their definitions of kalām. Imāmu'l-Ḥaramayn Abu'l-Ma'ālī al-Juwaynī (d. 478/1085), an Ash'arite scholar, defines kalām as follows: "Kalām is a discipline that allows knowing the universe ('ālam), its parts ('aqsām), its realities (haqāiq), its createdness (hudūth), the necessary and the impossible attributes of its creator (muhdith), and prophets, differentiating prophets from dishonest ones based on miracles, what is impossible and possible among the general principles of religion (sharī'a). al-Juwaynī, al-Burhān fi ușūl al-fiqh, (ed. 'Abd al-'Azīm alDib) Doha: Jāmi‘a Qatar, 1978, 1/84. 
relationship between kalām and natural sciences in a limited and superficial way, others have claimed that the mutakallimūn's engagement in physical sciences is much more profound. For instance, the renowned orientalist Montgomery Watt (1909-2006) states that the early mutakallimūn found the relationship between words more compelling than the causal relationship between material objects; accordingly, they were more interested in grammar and logic than in natural sciences. ${ }^{2}$ Sayyid Husain Nasr, in a similar vein, says that most of the Mu'tazili mutakallimūn only engaged in issues regarding theology, political-theology, and ethics; and that the interest over issues such as physics and natural sciences remained limited to some mutakallimūn like Abū Hudhayl al-`Allāf (d. 235/849-50 [?]) and al-Naẓāām (ö. 231/845). ${ }^{3}$

However, scholars such as Gerlof van Vloten (1866-1903), Georges Anawati (1905-1994), Anton M. Heinen, Joseph van Ess, Abdulhamid Ibrahim Sabra (1924-2013) Alnoor Dhanani, and Mohammad Basil Altaie depict the kalām-science relationship in a much deeper and comprehensive manner. For instance, van Vloten, in his book "Arab Natural Science in 9th Century", states that the word "mutakallim" indicates "natural scientist" "; similarly, Anawati points out that, in the early period, the scholars of kalām were sometimes called "physicist" (al-mutakallimūn fï al-țabīitiyyāt). ${ }^{5}$

In that vein, Anton M. Heinen asserts in his article entitled "Mutakallimūn and Mathematicians" that approaches to portray kalām as Islam's scholastic theology and accentuating its apologetic side are not compatible with historical kalām. For, according to him, the mutakallimūn paid much more attention to physical problems than what would be expected of a theologian. Moreover, in his opinion some mutakallimūn - such as al-Nazzāōm and al-Jăhiz - made invaluable contributions to the natural sciences through their experiments, observations and theories they developed in the period they lived. He also maintained that the critical approach of some noted Muslim scholars, like al-Bīrūnī, towards Aristotelian-Ptolemaic astronomy was affected by the mutakallimūn. Heinen suggests to those who find his expressions above exaggerated to glance through Abū alḤasan al-Ash'arī's Maqālāt al-Islāmiyyīn (The Doctrines of Muslims), a representative collection of the mutakallimūn's views and theories. For this reason, according to Heinen, it is not possible for historians to comprehensively explain the development of physical and mathematical sciences in the history of Islam unless the books of the mutakallimūn are also taken into account. ${ }^{6}$

\footnotetext{
W. Montgomery Watt, Free will and Predestination in Early Islam, (London: Luzac \& Comany Ltd., 1948), 88. Seyyed Hossein Nasr, Islamic Philosophy from its Origin to the Present, (New York: State University of New York Press 2006), 123.

4 Gerlof van Vloten, Ein arabischer Naturphilosoph im 9. Jahrhundert el-Dschâhiz (Stuttgart: 1918), 13.

4 Gerlof van Vloten describes the mutakallimūn as follows: "Even though mutakallimūn' works are essentially related to the dogmatic domain, their study methods required them to deal with physical problems extensively. There is hardly any scientific problem that they did not attempt to clarify. Greeks' teachings on atoms, natural qualities of elements, and the soul were also discussed by the mutakallimūn. Also, psychological matters were the focus of attention. Works were produced on self-knowledge and the nature of habits, original theories on the relationship of elements with each other were developed. It is noticed that occasionally the word "mutakallim" meant "naturalist" and "kalām" implied "philosophy." Gerlof van Vloten, Ein arabischer Naturphilosoph im 9. Jahrhundert elDschâhiz (Stuttgart: 1918), 13 etc. I first saw this quote in Anton M. Heinen's article "Mutakallimūn and Mathematicians", Der Islam 55/1 (1978), 59.

5 See. Georges C. Anawati, “Kalam” entry. Encyclopedia of Religion (second edition) (ed. Lindsay Jones) (USA: Macmillan, $2005,8 / 5059$.

6 Anton M. Heinen, “Mutakallimūn and Mathematicians”, Der Islam 55/1 (1978), 57-73.
} 
Joseph van Ess, who is one of the important researchers of the early kalām history, says that the main reason why the mutakallimūn engaged in natural sciences and cosmology was their desire to defend Islam against the religions and thought systems in the newly conquered areas. He also adds that the mutakallimūn later on turned this investigation into a pursuit of truth regarding the primary constituents of the universe and its way of functioning. According to him the empirical method for studying nature was used by some mutakallimūn in the Islamic world before the European Renaissance. Al-Nazzām's "experiments on the digestive system of ostriches" and discourses of the Basrian and Baghdadi branches of the Mu'tazila on the subject of void (khalā) are given as examples for this claim. ${ }^{7}$

Another remarkable researcher drawing attention to the mutakallimūn's interest in scientific and philosophical matters is Abdulhamid I. Sabra, was a professor of the history of science at Harvard University. He defines kalām in his article "Science and Philosophy in Medieval Islamic Theology, The Evidence of The Fourteenth Century" as "an inquiry into God, and into the World as God's creation, and into man as the special creature placed by God in the World under obligation to his creator." According to Sabra, despite kalām being a theologically inspired and theologically oriented form of thinking, the widespread prejudice towards kalām that it is essentially apologetics and a sectarian polemic has hindered its proper understanding. This approach reduces the prestige of the science of kalām as a theoretical discipline and prevents understanding the results of its intense interaction, especially with philosophy and science. Presenting kalām's great interest in philosophical and scientific matters through the example of the renowned Ash'arite mutakallim al-İjì's al-Mawāqif, Sabra reaches the following striking conclusion in his article: "It is not possible to describe, let alone explain, the outgrowth of philosophy and science in the Islamic world without considering their interaction with kalām."

In his doctoral dissertation titled Kalām and Hellenistic Cosmology: Minimal Parts in Basrian Mu'tazili Atomism ${ }^{9}$ written under the supervision of Abdulhamid I. Sabra, Alnoor Dhanani, shows how the role of the physical theories in the thought system of the mutakallimün formed a foundation for demonstrating and defending Islamic principles. ${ }^{10}$ Additionally, just as Josef van Ess did, Dhanani draws attention to the fact that cosmology occupied a central position in the mutakallimūn's debates with other religions and thought systems. ${ }^{11}$ However, according to him, an approach merely reducing the mutakallimūn's interest in natural phenomena to theological and apologetic debates doesn't do justice to their activities in this field. In his opinion, the mutakallimūn engaged

Josef van Ess, Theology and Science: The Case of Abū Ishaq al-Nažāam, Ann Arbor: Center for Near Eastern and North African Studies, University of Michigan, 1978; also see, Ahmet Mekin Kandemir, "The Hand Extending Beyond the Cosmos: Discussions on the Khalā' [Void] Between the Bașran and Baghdād Schools of Mu'tazila”, Nazariyat 7/1 (May 2021), 1-36.

8 Abdelhamid I. Sabra, "Science and Philosophy in Medieval Islamic Theology: The Evidence of the Fourteenth Century”. Zeitschrift für Geschichte der Arabisch-Islamischen Wissenschaften / Majallat Tārïh al-'Ulüm al-'Arabìa wa '-Islāmìya 9 (1994), 1-42.

9 Alnoor Dhanani published this work as The Physical Theory of Kaläm: Atoms, Space, and Void in Basrian Mu'tazili Cosmology (Leiden: Brill E. J. Brill, 1994).

10 Alnoor Dhanani, "Kalām and Hellenistic Cosmology: Minimal Parts in Basrian Mu'tazili Atomism", (Dissertation, Harvard University, 1991), 31 etc.

11 Dhanani, Kaläm and Hellenistic Cosmology, 46. 
in the natural sciences not only to reach theological conclusions but also to address physical problems as seekers of truth. Dhanani attempts to show the validity of this claim in the physics and cosmology-related discussions that the mutakallimūn deal with in their works in the sections called lațif (obscure), daqiq (subtle) or ghämid (difficult). ${ }^{12}$ According to him, if the mutakallimūn's only purpose was to defend Islam, they would not have developed opposing theories against other members of the same theological schools on physics-related matters; or tried to solve the physical problems unrelated to theology, and most importantly they would not have established such a complex and comprehensive cosmology. ${ }^{13}$ In conclusion, Dhanani argued that descriptions of kaläm's inquiries into scientific and philosophical issues - in particular by Peripatetic philosophers (falāsifa) - as a mere apologetic science cannot be tenable. ${ }^{14}$

It must be noted that there are also some researchers suggesting a middle way regarding the mutakallimūn's interest in philosophical and scientific matters. In his article titled "The Scientific Value of Daqiq al-Kalām" where he analyses the physical theories of the mutakallimūn with reference to modern science, Muhammad Bāsil al-Tāì, known for his studies on kalām-cosmology relationship, asserts that kalām is divided into two parts: "Jalil al-Kalām" under which matters such as God's existence, His attributes, revelation, prophethood, and afterlife are discussed, and "Daqiq al-Kaläm" under which nature, its structure, and its way of functioning are examined. While Jalil al-Kalām represents the revelation-based aspect of kalām, we find that the mutakallimūn engaged in matters related to natural philosophy in sections on Daqì al-Kalām. However, according to Tāī, the mutakallimūn did not have the same approach to examining the natural phenomena as did philosophers. They did not speak about God only based on nature or reason, but they considered the Qur'ān too, and thus they tried to understand nature in conformity with revelation. Moreover, in Tai's opinion, the aspect of the kalām examining nature started to be put aside over time; in contrast, the theology-related part of kaläm began to be emphasized more. Hence, neglecting Daqì al-kalām and focusing on Jalil al-kalām have resulted in lessening kalām's academic value and weakening its deep theoretical roots in the long run. ${ }^{15}$

\section{The Disctinction Between Jalil and Daqiq /Lațif Matters in the Classical Period of Kalām}

Although the analyses, as provided above, by contemporary scholars supply a general understanding of kaläm's relationship with science and philosophy, the most effective manner to approach the matter is a direct study of the available classical sources themselves. However, as

12 Alnoor Dhanani states that "The mutakallimūn distinguished between two aspects of kaläm. The first of these, which was based solely on reason, deals with 'obscure', 'subtle', or 'difficult' (latịf/daqia/ghämid) questions while the second deals with 'major' (jalil) questions [which depend on revelation]. (...) The topics covered by the 'subtle' questions deal mostly with cosmological concerns which, broadly speaking, consist of the problem of the nature and attributes of the things which constitute the world, the problem of the nature of man, and the problem of causation." See Dhanani, The Physical Theory of Kalām, 3-4.

13 Dhanani, Kalām and Hellenistic Cosmology, 36, 41, 43 etc.

14 Also see. Alnoor Dhanani, "Problems in Eleventh-Century Kalām Physics", Bulletin of the Royal Institute for Inter-Faith Studies, 4/1 (2002), 73-96. In this article, Dhanani calls historians of Islamic science also to take classical kalām books into consideration.

15 Muhammad Bāsil Al-Tāī, "The Scientific Value of Daqị̂ al-Kalām”, Islamic Thought and Scientific Creativity V/2 (1994), 7-18. 
also noted in the beginning, there are very few extant works from the early period of kalām, namely the $8^{\text {th }}-9^{\text {th }}$ centuries. Therefore, the study of this period depends upon the genre of maqālat literature, in which the views of earlier mutakallimūn are preserved fragmentarily in the form of certain subject headings. ${ }^{16}$

One of the earliest extant sources preserving information about the interest of the mutakallimūn in science and philosophy is the famous Mu'tazilī scholar Abū 'Uthmān al-Jāhiz' (d. 255/869) Kitāb al-Hayawān. Jāhiz' work is an encyclopedic text that attempts to explain the effects of the environment and climate on the different categories of zoology and the evolution of different types of animals. ${ }^{17}$ In the section titled "The Characteristics (awșāf) of the Mutakallimūn," Jāhiz says as follows:
"A mutakallim will not be able to master the complete scope of kalām as long as his proficiency in religion (kalāmal-dīn) is not on the same level as his proficiency in philosophy (kalām al-falsafa), and he will not succeed in acquiring the qualities needed for becoming an expert or reaching the level of a master ( $\left(r a^{\prime} \bar{s}\right)$ in this discipline. In our view, a scholar ('älim) is the one who can synthesize both in his person". ${ }^{18}$

It is remarkable to see a division of kalām subjects into religious and philosophical by al-Jāhịiz in a period that could be considered a relatively early period of kaläm, and his stipulation of becoming an expert in both in order to be a mutakallim. The text further indicates that by "philosophical theology" (kalām al-falsafa) al-Jāhiz refers to natural philosophy. According to al-Jāhiz, those who believe that they can establish the oneness of God (tawhid) through rejecting natures (tabä $i^{i}$ ) or excessively emphasizing the creator and disregarding the importance of creation, unwittingly weaken their understanding of tawhid. This is because the most powerful signs demonstrating God and His oneness are found in natures. Therefore, to remove the proofs is also to remove what they point to (madlūl). ${ }^{19}$

Another example for the use of the term "al-kaläm al-falsafa" can be found in Ibn al-Nadīm's (d. 385/995 [?]) al-Fihrist. While citing the names of the books written by al-Nazzām, al-Jāhiz's teacher, Ibn al-Nadīm states that al-Nazzāam follows the path of al-kalām al-falsafa in his poems. Ibn alNadīm also quoted a passage from a poem that Abū al-Nuwās (d. 198/813 [?]) wrote to criticize Naz̧āam's interest and involvement in philosophy. In that passage, Abū al-Nuwās suggests that even though al-Nažām was knowledgable in philosophy, he was not proficient enough in it. ${ }^{20} \mathrm{Ibn}$

16 Abū al-Ḥasan al-Ash'arī’s (d. 324/935) Maqālât al-Islāmiyyīn; 'Abd al-Qāhir al-Baghdādī's (d. 429/1037) al-Farq bayn alfiraq; Shahristān̄'s (d. 548/1153) al-Milal wa al-nihāl, and Ibn Hazm's (d. 456/1064) al-Fasl fi al-milal wa al-ahwā wa alnihāl can be listed.

17 This book is noteworthy in showing that a kalām scholar's interest was not limited to theological issues and covered scientific matters as well. For detailed information on al-Jāhị, see. Yusuf Şevki Yavuz, "Cahız", TDV İslâm Ansiklopedisi (DİA), 7/24.

18 al-Jāḥiz, Kitāb al-Hayawān, ed. Abd al-Salām Muḥammad Hārūn (Beirut: Dār Iḥyā al-Turāth al-'Arabī, 1388/1969), $2 / 134$.

19 al-Jāḥiz, Kitāb al-Hayawān, 2/135.

20 Ibn al-Nadìm, al-Fihrist, ed. Rizā Tajaddud (Tahran, 1971), 538-539. This passage can be translated as follows: "Tell the one who claims the knowledge of philosophy, you said something but also left out many." 
al-Nadīm's reference to "al-kalām al-falsafa" when introducing al-Nażāām demonstrates the widespread use of this expression at that period to describe kalām's interest in philosophy. ${ }^{21}$

The other term used in the $9^{\text {th }}$ and $10^{\text {th }}$ centuries in order to explain the mutakallimūn's interest in philosophical and scientific matters beside al-kalām al-falsafa is daqì al-kaläm or lațîf al-kaläm.

The Kitāb al-Intișār by al-Ḥusayn al-Khayyāț (d. 300/913 [?]), who was one of the leaders of the Baghdadī Mu'tazilite school, is one of the earliest surviving books in which this terminology is mentioned. This work is a refutation and rebuttal of Ibn al-Rāwandì's (d. 301/913-14 [?]), Fadihat al-Mu'tazila which he wrote against the Mu'tazila in general, and against al-Nażāam in particular." ${ }^{22}$ It is significant that a large part of al-Khayyāṭ's response to Ibn al-Rāwandī's defamations and criticisms against the Muctazila and al-Nazzāam involves philosophical and scientific subjects. In one of these criticisms, Ibn al-Rāwandī accuses the Mu'tazilites of being inconsistent and of upholding contradictory views and constantly debating each other. In his response to al-Khayyāt indicates that the Mu'tazilites argued mainly over tālī or far' (subsidiary) topics, and that it would be understandable for there to be no consensus in such topics. However, on major (jalil) topics such as tawhid, justice, prophethood, and revelation they would be in agreement. ${ }^{23}$ According to al-Khayyāț, these tāli matters are of the difficult and obscure subjects of kalām (min ghāmiḍi al-kalāmi wa lațîihi). Some of them are e.g. the continuation (baqāa) and annihilation $\left(f a n \bar{a}^{3}\right)$ of entities; the ma'nā theory that was developed to explain resting bodies and moving bodies; the categorization of objects (mujānasa); the question whether objects interpenetrate (mudākhala); and the acquisition of knowledge and the nature of man. ${ }^{24}$ Non$\mathrm{Mu}^{\mathrm{c}}$ tazilites would not be on the necessary level to understand or discuss these subjects unless by way of plagiarizing from the Mu'tazila. Therefore, other schools were not able to state opinions pertaining to these subjects, so the $\mathrm{Mu}^{\mathrm{c}}$ tazilites could not actually dispute with them. In these issues, the Mu'tazilite scholars would be their only opponents and for this reason, they enter into debate with one another. ${ }^{25}$ In the proceeding sections of the book, al-Khayyāt asserts his views

21 Also, it is noteworthy that Ibn al-Nadīm used the term "Faylasūfal-"Arab" when referring to al-Kindī, a contemporary of al-Naẓāām, while he used the expression "kalām al-falsafa" for al-Naz̧⿻ām. As a result, al-Naẓzāam can be considered to be someone who engaged philosophy in kalām. See. al-Fihrist, 828 .

22 For information on Abū al-Ḥusayn al-Khayyāț, see. Şerafettin Gölcük, "Hayyât”, DİA, 17/103.

23 Abū al-Ḥusayn al-Khayyāț, Kitāb al-Intișār, ed. Albert Nasri Nader (Beyrut 1957), 137.

24 al-Khayyāt says in a different place in his book as follows: "Have you said that disagreements among them (al-Jāhị and his friends) are only on annihilation $\left(f a n \bar{a}^{3}\right)$ and persistence $\left(b a q \bar{a}^{\overrightarrow{ }}\right)$ of the things, the maina theory, known ( $m a^{c}$ lüm) and unknown (majhūl) things, the one who is hindered and the one who achieve, impossibility of enduring injustice, and secondary causation (tawallud)? These issues are kalām's obscure (latị̂f) and subtle (daqiq) issues, and these types of issues sometimes lead scholars to doubt. Ibid. 106.

25 al-Khayyāț, Kitāb al-Intișār, 14. "These issues mentioned before are among the daqĩ and lațîf issues of kalām, which Răfidites cannot fathom. Indeed, the fact that only a Mu'tazilī opposed to another Mu'tazilī in these matters you mentioned one by one, is proof of this. You realize that the attempts of non-Mu'tazilis in [dealing with] these matters are nothing but stealing the Mu'tazili teaching and adapting it themselves." Also, al-Khayyāṭ stated that a lot of conflicts arose among people concerning daqiq and latiif issues and found this normal: "Know that -may Allah guide you to goodness- regarding the annihilation of something, the questions whether or not annihilation is other than this thing or whether it inheres in this thing, or another thing are among daqiq and latif issues of kalām. There has been great disagreement among people about these issues." See. Ibid, 19. "A mistake of any Mu'tazilī is related to the detail of latiif/daqiq issues of kalām. Did not you report some of their mistakes about annihilation or persistence 
with growing clarity. For example, in responding to Ibn al-Rāwandī's criticism of al-Nažāam's views on the interpenetration of sounds, al-Khayyāt writes the following:

"The nature of sounds and the question of how hearing is achieved is one of the obscure and difficult subjects of kalām (min lațif al-kalāmi wa-ghāmidihi). On this subject, there are no views other than those of the Muctazilites. Only the Mu'tazilites can discuss these subjects because they have achieved a level of mastery in kalām first in the major and explicit subjects of kalām and also in the subtle and difficult subjects (bi-daqiq al-kalāmi ve ghāmidihi)". ${ }^{26}$

Here, we see that while al-Khayyāt defines the subjects that are the essentials of religion and with which the Mu'tazilites are in agreement as "jalì al-kalām," he denotes "daqia/latîif/ghāmid alkalām", i.e. the subjects pertaining to physics, such as the nature of sounds and how hearing is achieved, and where there is disagreement between the Mu'tazilites, as subsidiary (tälī) topics. ${ }^{27}$ This is showing that the distinction between jalil al-kalām and daqīq al-kalām in the science of kalām goes back at least to the $9^{\text {th }}$ century.

\begin{tabular}{|c|c|}
\hline \multicolumn{2}{|c|}{ KALĀM'S JALİL AND DAQĪQ/LAṬIIF MATTERS ACCORDING TO AL-ḤAYYĀT } \\
\hline JALİL MATTERS & DAQĪQ/LAṬIF MATTERS \\
\hline -Divine oneness (Tawhīd) & -The annihilation $\left(f a n \bar{a}^{\prime}\right)$ or continuation $\left(b a q \bar{a}^{\prime}\right)$ of things $\left(a s h y \bar{a}^{\prime}\right)$ \\
\hline -Divine justice ('Adl) & -The theory of knowledge (what is known ( $m a$ lüm) and what is \\
\hline -Prophethood (Risāla) & not known (majhūl)) \\
\hline -Revelation (Wahy) & -The theory of secondary causation (tawallud) \\
\hline & -The categorisation of the objects in the World (mujānasa) \\
\hline & -The discussion of the whole and the part, the finite and the \\
\hline & infinite. \\
\hline & -The nature of man and of knowledge. \\
\hline
\end{tabular}

The chart above shows that by major issues al-Khayyāt, usually refers to revelation-based theological questions over which there is general agreement; whereas by obscure or subtle matters, he means reason-based questions over which they differ. In addition, it is also remarkable in terms of indicating the degree to which the mutakallimūn were involved in scientific and philosophical studies that al-Khayyāt proudly asserts that only the Mu'tazilite mutakallimūn dealt with latif and daqiq matters at a period in which Muslim Peripatetic philosophy (falsafa) had not yet emerged. On the other hand, writing about daqiq and lațif subjects of kalām as subsidiary matters ( $f a r c)$ does not mean that these subjects were unimportant. Indeed, according to alKhayyāt, the mutakallimūn used their discussions on the relationship between the part and the whole, and between finite and infinite as a means to support tawhid and refute the deniers. ${ }^{28}$

of things, known and unknown, secondary causation (tawallud), and [Mu'ammar's] ma'na theory when you tried to reveal the Mu'tazila's faults? Răfidites already do not understand these matters." Ibid, 146.

26 al-Khayyāt, Kitāb al-Intișār, 43.

27 al-Khayyāṭ also uses terms daqiq and jalil in place of particular and main issues. When answering Ibn al-Rāwandī, he claims that God eternally knows the reality of daqiq and latifi matters through His essence, not with a type of knowledge outside Himself. Ibid. 112.

28 al-Khayyāt, Kitäb al-Intișär, 15. "This view is a significant issue that is the essence of tawhìd. That is related to what has been and what will be, finite and infinite, the whole (kull) and part (juz'). Those who are concerned about tawhid and rebuttal of unbelievers deal with these issues." Ibid. 15; Al-Khayyāt stated that famous Mu'tazilī scholar al- 
Therefore, here, al-Khayyāt offers an integrative method that requires expertise in both theological and scientific matters, which was, before him, pointed at by al-Jāhiz when talking about kaläm al-dīn and kalām al-falsafa.

Another text through which we may acquire a better understanding of the distinction between matters of jalīl and daqī issuesof kalām is al-Ash'arī's Maqālāt al-Islāmiyyīn (The Doctrines of Muslims). This work is of unparalleled significance for the study of the thought of the early mutakallimün whose works have not survived. Moreover, the classification undertaken by alAsh'ari in this book in relating the thoughts of the mutakallimūn regarding faith and the universe is of particular importance. al-Ash'arī concludes the section of his book dedicated to those views that led Muslims to form different sects with the statement "This is the end of the discussion on the major subjects (hādhā ākhir al-kalām fi al-jalil)"; while the section dealing with subsidiary matters that have not led to division within the Muslim community commences as follows, "this is the beginning of the discussion of the subtle (daqiq) subjects (hādhā dhikr ikhtiläf al-nās fi aldaqia)". We see in the section about jalil al-kalām that it usually contains "theological" matters such as oneness of God, prophethood, and revelation; in the section on daqiq al-kalām we see different views on cosmological issues including the atom, bodies, accidents, motion, causality. ${ }^{29}$

al-Ash'ari’s systemization of jalil and daqiq matters in his book and the content in the section of daqiq al-kalām are in apparent conformity with al-Khayyāț's previously described approach. Hence, the science of kalām includes matters it deems to be Islam's foundations, which are called jalil; and it also includes subsidiary issues named "daqiq" or "lații" that are not part of the foundational principles of Islam. While aspects that classify as jalil matters are faith-related and mostly based upon the revelation, daqiq matters deal with reason-based epistemological, ontological, and cosmological issues. Therefore, having different opinions in jalil matters leads to sectarian divisions, while differing in daqiq matters, conversely, does not have such a consequence. ${ }^{30}$

An approach that is similar to al-Ash'ari’s can be seen in the Kitäb al-Maqālāt of his contemporary Abū al-Qāsim al-Balkhī al-Ka'bī (d. 319/931), who is an important representative of the Baghdadī school. The first section of al-Ka'bi's work deals more with theological matters such as God's essence, His attributes, the Qur'ān's characteristics, and prophethood. Later on the heading "bāb al-qawl fi al-latîif' (chapter on lațif matters) includes more philosophical and scientific issues like

Nažāām also said in his deathbed that he has engaged with daqiq/lațif matters to defend tawhï and prayed as follows: "Shame on Ibn al-Rāwandī! While people of the world were immersed in pleasures and chasing after worldly blessings, al-Nažāām and Muslim scholars like him devoted themselves to tawhīd and endeavored to defend it. They tried to protect tawhid against the attacks of unbelievers. They made efforts in answering apostates (mulhids) and produced works against them. Many of our friends told me that al-Nažzām entrancedly prayed as follows: "My God! You know that I did not refrain from anything to prove Your oneness (tawhìd), and I only acknowledged latiif and daqiq issues of kalām to reinforce tawhìd and tried to stay away from those opposing tawhìd. My God! Since you know me as I have described, then forgive my sins, and ease death for me." My friends told me that al-Nażāam passed away during this prayer. Departing this life in this manner is for those who know and fear Allah. God is the One who rewards those who are grateful like this." See. Ibid. 41-42.

29 al-Ash'arī, Abū al-Ḥasan, Maqālāt al-Islāmiyyīn wa ikhtilāf al-mușallīn, ed. Hellmut Ritter (Wiesbaden:1963), 181-182.

30 It is known that Imām al-Ash'arī wrote a non-surviving book named Kitāb al-nawādir fi daqā'iq al-kalām, where he discussed issues such as bodies, atoms, human nature, space, accidents, and motion. See. Dhanani, Kalām and Hellenistic Cosmology, 28-29. 
the structure of bodies and the question whether it is composed of the smallest particles or not, the properties of accidents, the nature of the human, natural actions, cognition, time, place, etc. ${ }^{31}$

The approach of discussing scientific and philosophical subjects under the heading "lațif al-kaläm" is also present in the Awā'il al-maqālāt of the Shiite intellectual Shaykh al-Mufīd (d. 413/1022). AlMufid presents subjects like substance/atom, accidents, bodies, non-existent, the nature of the world, the shape of the earth, void and fullness, place, time, natures, and engenderment/ secondary causality (tawlìd) under this heading. ${ }^{32}$ As such, if we consider all three Maqālāt works together, we see that the mutakallimūn treat rational and scientific subjects under the terminology of lațîf al-kalām and daqia al-kalām. Furthermore, these works clearly demonstrate that the mutakallimūn were deeply interested in scientific and philosophical subjects alongside of theological and religious subjects.

Another classical work showing the correlation between lațif/daqiq matters to philosophical and scientific issues is Ibn Fūrak's (d. 406/1015) Mujarrad maqälāt al-Shaykh Abī al-Hasan al-Ash'arī (The pure doctrines of al-Ash'ari). This text is vital in elaborating al-Ash'ari’'s views. Indeed, although alAsh'arī's narrates the views of many of his contemporaries and predecessors in his own Maqālāt, he does not, out of the principle of impartiality, express therein his own thoughts. Also, al-Ash'arī does not comment on regarding the theological background of the philosophical and scientific concepts defended by the mutakallimūn mentioned in his work. However, the $37^{\text {th }}$ section of Ibn Fürak's work "The other inquiry regarding the clarification of the views of al-Ash'arĩ on latîf and daqiq subjects" is entirely concerned with expounding al-Ash'arī's views on substance/atoms and accidents. Here, we see that al-Ash'arī endorsed atomism, accepted the existence of the void, adopted the notion of God's custom ('a da) on the functioning of the universe, and thus denied necessary causality. In addition, Ibn Fürak provides here the theological backdrop to the cosmological views defended by al-Ash'arī. According to Ibn Fûrek, al-Ash'arī defined terms such as substance/atom, accident, and body in a theistic framework and explained the concept of "atom" (al-jawhar al-fard) by connecting it to the principle of tawhid, i.e the oneness of God. ${ }^{33}$

The most explicit statements regarding the role and place of daqiq subjects in kalām and their relationship with theological matters are found in al-Muhịt bil-taklif of al-Qādī 'Abd al-Jabbār (d. 415/1025), the famous mutakallim of the Basrian Mu'tazila. Here, 'Abd al-Jabbār indicates that there are five fundamentals (ușūl) that a mukallaf(religiously accountable person) must know in relation to God's existence and His oneness, and he explains it as follows:

\footnotetext{
${ }^{31}$ Abu'l-Qāsim al-Balkhī al-Ka 'bī, Kitāb al-Maqūāāt wa ma 'ahu 'Uyūn al-masā ’il wa al-jawābāt, ed. Hüseyin Hansu Rājih Abdulhamīd Kurdī (Istanbul, Amman: KURAMER, Dār al-Fath 2018), 441 etc.

${ }^{32}$ See. Shaykh al-Mufīd, Awā’il al-maqālāt, ed. Mehdī Muhaqqiq (Tahran: Dānishgāh-e Tahrān, 1372/1993), 40 etc. Shaykh al-Mufid, who was clearly influenced by the Baghdadi Mu'tazila, despite accepting atom's existence (jawhar al-fard), associated cosmological matters with "tawhï," for instance, regarded deniers of atom's existence as unbelievers, just as Imām al-Ḥasan did. He says as follows: "Bodies (ajsām) consist of indivisible atoms. Except for some apostate (mulhid) M'utazilites, everyone who believes the oneness of God accepts this premise."

See. Shaykh al-Mufīd, Awāil al-maqālät, 40; For Shaykh al-Mufīd's cosmology understanding, also see. Martin J. Mcdermott, The Theology of al-Shaikh al-Mufid (Beyrut: 1978), 189 etc.

33 Ibn Fūrak, Mujarradu maqālāt al-Shaykh Abi al-Hasan al-Ash'arī. ed. Daniel Gimaret (Beyrut: Dār al-Mashriq 1987), 202.
} 
"These fundamentals are only completed by the subsidiary $(t \bar{a} l \bar{l})$ subjects. This is the reason why our friends speak on the daqiq issues. The foundational principles are explained in order to correct the argument, respond to questions, and remove doubts. And this includes proving the existence of temporal beings (hädith) that point to the existence of God and speaking about the temporality of bodies and things that are not bodies. There are innumerable examples for daqiq matters. For instance, if it was argued that an infinite number of bodies exists because there was an infinite amount of numbers, the theory on the atom (juz') would be needed to refute it. This also applies to proving the existence of the Creator. On this, one has to be able to confront Zakariyyā' al-Rāzì [d. 313/925], who argues that God has not the power to create the essence of the matter, and dispute with him. In the same way, you need to dispute with him on time and space [which he considers to be eternal] too..." ${ }^{34}$

As can be seen here, al-Qāḍ̄ ‘Abd al-Jabbār terms cosmological matters such as the creation of the universe, body, atom, space and time as daqiq subjects, and categorizes them as the subsidiary matters by which the fundamentals of tawhid are established and defended. Therefore, his approach to this subject corresponds to those of his predecessors al-Jāhị, al-Khayyāt and alAsh'arī. On the other hand, al-Qāḍ̄ ‘'Abd al-Jabbār also uses the term "daqīq al-kalām" in referring to other mutakallimūn. For example, in speaking of Abū al-Hudhayl al-'Allāf in his work Fadl ali'tizāl wa Țabaqāt al-Mu'tazila, 'Abd al-Jabbār notes that Abū al-Hudhayl al-'Allāf conversed with Hishām b. al-Ḥakam and others and disputed on daqī subjects. ${ }^{35}$ He also says about Nażām, the cousin and student of Abū al-Hudhayl the followings:

"Ibrāhīm al-Naz̧āàm was one of his [Abū al-Hudhayl] students. As he was on his way to the Hajj, he met Hishām b. al-Hakam and others. He discussed with them the daqiq subjects of kalām. He also read the works of the [ancient] philosophers. Later, he returned to Basra, believing that he resolved kalām's difficult and confusing subjects (min lațif al-kalām), which others before him had failed to understand". ${ }^{36}$

A Mưtazilite biographical author al-Ḥākim al-Jushamī (d. 494/1101) when speaking of al-Qāḍ̄ 'Abd al-Jabbār's prestige and influence among the Mu'tazilites, distinguished between the jalil and daqiq subjects of kalām:

"I have not found any accounts that harm the reputation of al-Qāḍi 'Abd al-Jabbār, his high status, virtue and knowledge. This is because he has revealed kaläm for others and achieved important works in this pursuit. Because of his efforts, kalām spread to the East and the West and to the near and far four corners of the world. In his works, in addition to the jalil issues of kaläm, he also examined the daqiq subjects of this science in a way that has never been achieved before by any other person". ${ }^{37}$

An report attributed to al-Qāḍī 'Abd al-Jabbār's student Abū Rashīd al-Nīsābūrī (d. 415/1024) clarifies what is meant here by "daqiq subjects". It is narrated that when he was in the academic circle of al-Qāḍī `Abd al-Jabbār, al-Nīsābūrī decided to sort the kalām-related authoritative rulings

34 al-Qāḍī ‘Abd al-Jabbār, al-Majmū' fï al-muhịt bi al-taklīf, ed. J. J. Houben (Beyrut: Dār al-Mashriq, 1986), 26-27.

35 al-Qāḍī ‘Abd al-Jabbār, Faḍlu al-i'tizāl wa Ṭabaqāt al-Mu'tazila (in Faḍlu al-ítizāl wa Ṭabaqāt al-Mu'tazila) ed. Fuād Seyyid (Tunus 1393/1974), 254.

36 al-Qāḍī 'Abd al-Jabbār, Faḍlu al-i'tizāl, 26.

37 al-Ḥākim al-Jushamī, Sh harḥ al-‘Uyūn (in Faḍlu al-i'tizāl wa Ṭabaqāt the Mu`tazila), ed. Fuād Seyyid (Tunus 1393/1974), 365 . 
(fatāwā) of his teacher in a book (Dīwān al-ușūl) and ranked the subjects of body and accident before the subjects of tawhīd and justice ('adl) in this work; however, al-Qādī 'Abd al-Jabbār did not approve of this classification and requested that jalil subjects must be treated before daqiq ones. In this case, it can be understood that according to al-Qādīi, issues such as body and accident fell under the category of daqiq and those such as tawhìd and justice under that of jalil..$^{38}$

The distinction between jalì and daqì in kalām can also be seen in the Zaydī Ibn al-Murtadā (d. 840/1437). In commenting on works written by mutakallimūn, Ibn al-Murtad̄ā differentiates between daqī al-kalām and jalī al-kalām. While introducing Jācfar b. Harb (d. 236/850) in his alMunya, he notes that Jācfar ibn Harb was a very ascetic and knowledgeable person of his time and compiled many works on jalī and daqiq issues of kalām. ${ }^{39}$ Also, in relation to Abū al-Hudhayl, he says that "it was narrated from Yahyā ibn Bishr that Abū al-Hudhayl al-'Allāf refuted his opponents in around sixty works on daqī al-kalām and jalil al-kalām." ${ }^{40}$

On the other hand, the distinction between jalil and daqiq issues in classical kalām was also used by those out of kalām. For example, in the Risāla fì thamarāt al-'ulūm of Abū Ḥayyān al-Tawhīdì (d. 414/1023), an important master of Arabic prose, kalām is introduced as a science consisting of two parts, rationally based (yatafarradu al-'aql bihi), daqī and based on revelation (yufza'u ilā kitāb Allähi fïhi), jalil. ${ }^{41}$

Lastly, it should be noted that the distinction of daqiq al-kalām and jalil al-kalām has also been used to condemn the mutakallimūn. Some Zaydī-Salafī scholars like Ibn al-Wazīr (d. 840/1436) criticized certain mutakallimūn, such as al-Hâkim al-Jushamī, and Ibn Mattawayh, for their view that the soul merely consisted of breath and air, which they based on their atomic cosmology. Ibn al-Wazir associates the root of this problem with the mutakallimūn's engagement with daqia al-kalām. ${ }^{42}$ Referring to Ibn Mattawayh's Tadhkira, Ibn al-Wazīr opens a chapter titled "the mutakallimūn's withdrawal from dealing with daqiq al-kalām", and here, he claims that mutakallimūn are doomed unless they disassociate themselves from daqiq al-kalām. al-Ḥākim al-Mu'tazilī, in his outstanding treatise about ma`rifa Allah (knowing Allah), says: "Jā‘far b. Ḥarb and Jā‘far b. Mubashshir among the mutakallimūn stopped engaging in daqĩq al-kalām. Al-Ghazālī, in his Ihya 'Ulūm al-Dīn, also took a similar stance on this issue, and did not consider treating these matters in detail necessary." 43 Under another heading named "The way to be saved from kaläm," Ibn al-Wazir asserts that indulging in kalām is unnecessary by pointing out to al-Tadhkira and Fakhr al-Dīn al-Rāzìs

38 See. Ma‘n Ziyāda-Rıdvān Sayyīd, al-Masāỉl fì al-khilāf bayn al-basriyyīn wa al-Baghdādiyyīn (Abū Rashīd al-Nīsābūrī’s foreword), Beyrut 1979, 6.

39 Aḥmad ibn Yahyā al-Murtaḍā, Bāb Dhikr al-Mu'tazila min Kitāb al-Munya wa al-amal, ed. Thomas Walker Arnold (Leipzig 1902), 41.

40 Ibn al-Murtaḍā, Kitāb Tabaqāt al-Mu'tazila, ed. Susanna Diwald Wilzer (Beirut: Maktabat al-Hayāt), 44.

${ }^{41} \quad$ Abū Ḥayyān al-Tawhīìi, Kitāb al-Adab wa al-inshā fí al-șadaqa wa al-șadīq (Cairo 1323/1905), 192.

42 Ibn al-Wazīr, İthār al-ḥaqq 'alā al-khalq. ed. Anū 'Abd al-Raḥmān Nabil Salah 'Abd al-Majīd Salīm. Samanud (Eygpt), Maktaba Ibn 'Abbās, 2010, 1/59; For Ibn Mattawayh's views on the soul, see. Ibn Mattawayh, al-Tadhkira fi ahkām aljawāhir wa al-a'rāạ, ed. Daniel Gimaret (Cairo: al-Ma'ha al-Fransī, 2009), 2/380, 386-387; For Ibn Mattawayh's views on cosmology, see. Metin Yıldız, Kelam Kozmolojisi Mu'tezilenin Âlem Anlayışı (Istanbul: Endulus, 2020); al-Ash'arī has similar ideas on the soul to Ibn Mattawayh. See. Ibn Fūrak, Mujarrad, 267.

43 Ibn al-Nadìm, al-Fihrist, 204. 
Muhașsal. ${ }^{44}$ According to Ibn al-Wazir, to substantiate sublime issues by means of low-level methods is not right. Indeed, diving into profound issues using this method can neither help with doubts nor remove them. He further says on the issue: "Jubbāī and Mattawayhī treatment cannot help a person who could not benefit from divine and prophetic treatment." ${ }^{45}$

In summary, the conclusion to be reached through all of these works is that since the early periods, kalām issues are divided into two parts: jalil al-kalām and daqiq al-kalām..$^{46}$ Accordingly, issues pertaining to Islam's fundamentals, such as God's essence and His attributes, prophethood, afterlife, and revelation, are termed jalil al-kalām; matters related to epistemology, ontology, physics, and cosmology are named daqiq al-kalām or lațif al-kalām. The first part (jalil) is mostly based on revelation; in contrast, the second part is based on reason. Moreover, since this part is not directly a component of faith principles and counted as subsidiary, it does not lead to sectarian divisions. As we cited above from some mutakallimūn like al-Jāhiiz, al-Khayyāț, al-Ash`arī, Ibn Fūrak, Shaykh al-Mufīd, and al-Qādị 'Abd al-Jabbār, the purpose of the second part of kalām is to build a foundation for the jalil matters, especially "the principle of tawhid," and to function as a means to defend it.

\section{The Main Scientific and Philosophical Issues that the Scholars of Kaläm were Occupied with under the Heading of Daqiq and Latiif Matters}

After showing that the mutakallimūn divided the subjects of kalām into those based on revelation, jalil al-kalām, and those based on reason, daqiq al-kalām, the question of what kind of scientific and philosophical matters they discussed under the category of daqiq or latiif issues arises. In this chapter, I will attempt to identify that in which matters the $9^{\text {th }}$ and $10^{\text {th }}$-century scholars, whose works are not extant, were more interested in, especially based on the daqia or lațif al-kalām chapters in the Maqālāt books of al-Ka'bī, Shaykh al-Mufīd, and al-Ash'arī. However, while doing so, two other very important books representing approximately the same period will be used. For this purpose, a list of scientific and philosophical books which were attributed to the mutakallimūn of $9^{\text {th }}$ and $10^{\text {th }}$ centuries in Ibn al-Nadim's al-Fihrist will be presented. Even though these books are not available today and there is no information about their contents, their titles will provide us an insight into the subjects of the books written on the daqiq al-kalām by the mutakallimün. Then, some information will be given about the content of Ibn Mattawayh's al-Tadhkira fi ahkām aljawāhir wa al-a'rāe (On the Properties of Substances/Atoms and Accidents), which is also titled as Tadhkira fi latiif al-kalām. ${ }^{47}$ This book will provide us an opportunity to discern how Ibn Mattawayh treated the terms, substance/atom (jawhar) and accident ('arad), which he considered among the latif or daqiq issues of kalām. Thus, through three different works, the kind of philosophical and scientific issues that the mutakallimūn discussed under the headings of daqiq and latifi matters between the $9^{\text {th }}$ and $10^{\text {th }}$ centuries will be revealed.

$44 \quad$ Ibn al-Nadìm, al-Fihrist, 204.

45 Ibn al-Wazīr, Tarjīhu asālib al-Qur'ān 'alā asālib al-Yūnān (Bairut: Dār al-Kutub al-'ilmiyyah, 1984), 91. For detailed information, see. Metin Yıldı, İbn Metteveyh'in Kozmoloji Anlayışı, 35.

46 In al-Jāhịiz, this division is in the form of "kalām al-dīn-kalām al-falsafa". See. Kitāb al-Hayawān, $2 / 134$.

47 See. Kalām and Hellenistic Cosmology, 26. 
Starting with the Maqālāt books, major scientific and philosophical subjects that al-Ash'arī examined under the title of "Views of People on Subtle (daqīq) Issues" in his Maqālāt al-Islāmiyyin can be listed as follows: ${ }^{48}$

\begin{tabular}{|c|c|}
\hline \multicolumn{2}{|c|}{$\begin{array}{l}\text { SOME HEADINGS FROM THE DAQĪQ } \\
\text { CHAPTER OF AL-ASH'ARİ'S MAQĀLĀTT }\end{array}$} \\
\hline Quiddity (māhiya) of the body (jism) & $\begin{array}{l}\text { Whether five senses are homogenous } \\
\text { (mutajānis) or different genera }\end{array}$ \\
\hline $\begin{array}{l}\text { Controversy (ikhtiläf) over substance (jawhar) } \\
\text { and its meaning }\end{array}$ & Motions, rest, and actions \\
\hline Whether all substances are bodies or not & $\begin{array}{l}\text { Homogeneity of motions and whether they } \\
\text { are one genus or not }\end{array}$ \\
\hline $\begin{array}{l}\text { Whether substances are homogenous (jins } \\
\text { wāhid) or not }\end{array}$ & $\begin{array}{l}\left.\text { Whether accidents ( } a^{c} r \bar{a} d\right) \text { are perpetual or } \\
\text { not }\end{array}$ \\
\hline $\begin{array}{l}\text { Whether decomposition of the body [into } \\
\text { atoms] is possible }\end{array}$ & Whether accidents cease to exist or not \\
\hline Existence of two movements in one part (juz') & Persistence $\left(b a q \bar{a}^{\prime}\right)$ and annihilation $\left(\right.$ fan $\left.\bar{a}^{3}\right)$ \\
\hline Leap (tafra) & $\begin{array}{l}\text { Conversion of accidents into bodies and } \\
\text { visa-versa }\end{array}$ \\
\hline $\begin{array}{l}\text { Movement of a thing to another place while its } \\
\text { place is moving }\end{array}$ & $\begin{array}{l}\text { Whether the motion is motion due to its } \\
\left.\text { essence and without a quality ( } m a^{\mathrm{c} n a}\right) \text {. }\end{array}$ \\
\hline $\begin{array}{l}\text { Controversy (ikhtiläf) over the standing (wuqūf) } \\
\text { of the earth }\end{array}$ & $\begin{array}{l}\text { Permissibility of bringing back the } \\
\text { accidents }\end{array}$ \\
\hline $\begin{array}{l}\text { Interpenetration (mudākhala), latency } \\
\text { (mukāmana) and proximity (mujāwara) }\end{array}$ & Perception (idräk) of perceptible things \\
\hline Quiddity (māhiya) of human & Cause of the perception \\
\hline Knowledge of color through senses. & The thing seen in the mirror \\
\hline Engenderment/secondary causation (tawallud) & Place (makân) \\
\hline Weight and lightness & Time (waqt) \\
\hline $\begin{array}{l}\text { Whether the shadow of thing is that thing or } \\
\text { something else }\end{array}$ & Known (ma'lüm) and unknown (mechūl) \\
\hline Life (hayāt) & Causes (asbāb) \\
\hline $\begin{array}{l}\text { How the sound is heard and whether its } \\
\text { transmission is possible or not }\end{array}$ & $\begin{array}{l}\text { The subject of senses and the possibility of a } \\
\text { sixth sense }\end{array}$ \\
\hline Whether sound is a body (jism) or not & The soul, anima, and the life \\
\hline Ideas/thoughts (khawātir) & $\begin{array}{l}\text { The one who reaches his hand beyond the } \\
\text { universe }\end{array}$ \\
\hline
\end{tabular}

$48 \quad$ al-Ash`arī, Maqālāt, 301. 


\section{God's creation of the universe without being in $\quad$ Removal of air (hav $\left.\bar{a}^{\prime}\right)$ from the space} a place (makān)

What strikes us the most about the headings is that that the mutakallimūn were mostly interested in philosophical and scientific issues related to physics and cosmology. Accordingly, the mutakallimūn intensely discussed such issues as the essential elements forming the universe, the structure and properties of objects, their change and continuity, substance and accident, and causality. In addition, they were also intrigued by some other issues such as human essence, senses, perception, soul, breath, and life. Besides, what al-Ash'arī recounted under different headings shows that the mutakallimūn, in that period, made a special effort to explain motion.

Another remarkable thing in al-Ash'arī's book is the richness of discussions among the mutakallimūn especially on physics-related matters. Although the discussions took place mainly between the Basrian and Baghdadi schools of the Mu'tazila, when examined in detail, there was hardly any mutakallim who did not have an opinion on subjects such as the structure of the objects, substances, accidents, and causality. For instance, al-Ash'arī stated that the mutakallimūn were divided into twelve groups regarding the structure of the objects. ${ }^{49} \mathrm{He}$ also indicates that the mutakallimūn were split up into fourteen groups as to whether objects can be divided into the smallest part. As for the content of these discussions, it can be said that the mutakallimūn developed some complicated theories and original terms, such as leap (țafra), latency (kumūn), manifestation/appearance (zuhūr), engenderment/secondary causation (tawallud), custom ('āda), interpenetration (tadākhul). This shows that the mutakallimūn fully incorporated scientific and philosophical matters. Hence, a community interested in epistemological and cosmological issues was formed.

After al-Ash'arī's Maqālāt, we encounter a similar case when we look at the Kitāb al-Maqālāt of Abu'l-Qāsim al-Balkhī al-Ka‘bī (d. 319/931), one of the Baghdadī school leaders. Like al-Ash'arī, alKa'bī has a chapter titled "the chapter on lațif issues" (bābu'l-qawli fìl-lațîf) in which he deals with the philosophical and scientific views of the mutakallimūn. ${ }^{50}$ Headings of philosophical and scientific ideas that al-Kacbī attributed to the mutakallimūn can be listed as follows:

\begin{tabular}{|c|c|}
\hline \multicolumn{2}{|c|}{ SOME HEADINGS OF THE LAȚİF CHAPTER OF AL-KA'Bİ'S MAQĀLĀT } \\
\hline $\begin{array}{l}\text { Views (al-qawl) on whether "non-existent" } \\
\text { (ma'dūm) is "thing" (shay') or not }\end{array}$ & Views on natural actions ( $\left.a f^{\prime} \bar{a} l u^{\prime} t-t+i b \bar{a}^{\prime}\right)$ \\
\hline $\begin{array}{l}\text { Views on the quiddity of the body (jism) and } \\
\text { its other states (ahwāl) }\end{array}$ & $\begin{array}{l}\text { Views on perception (idrāk) and senses } \\
\text { (hawās) }\end{array}$ \\
\hline $\begin{array}{l}\text { Views on the earth, its origination, and the } \\
\text { whole universe ('âlam) }\end{array}$ & Views on latency (kumūn) \\
\hline $\begin{array}{l}\text { Views on one of the two stones passing the } \\
\text { other when thrown }\end{array}$ & Views on air $\left(h a v \bar{a}^{\prime}\right)$ \\
\hline
\end{tabular}

\footnotetext{
${ }^{49}$ al-Ash'arī, Maqālāt, 301.

${ }^{50}$ al-Ka'bī, Kitāb al-Maqālāt, 441 etc.
} 


\begin{tabular}{|c|c|}
\hline $\begin{array}{l}\text { Views on whether it is possible to divide the } \\
\text { [indivisible] part (juz') of the body }\end{array}$ & Views on place (makān) \\
\hline Views on accidents ( $\left.a^{c} r \bar{a} d\right)$ of the body & Views on time (waqt) \\
\hline Views on human ('insān) & $\begin{array}{l}\text { Views on whether someone looking at the } \\
\text { universe will see something or whether their } \\
\text { hand can reach it when they extend their } \\
\text { hand or not }\end{array}$ \\
\hline $\begin{array}{l}\text { Views on creation }(k h a l q) \text {, persistence }\left(b a q \bar{a}^{\top}\right) \text {, } \\
\text { annihilation }\left(\text { fana } \bar{a}^{\prime}\right) \text {, and re-creation ( }\left(i^{\prime} \bar{a} d a\right) \text { of } \\
\text { something }\end{array}$ & Views on a particle (zarra) on a large ship \\
\hline $\begin{array}{l}\text { Views on whether causes precede the effects } \\
\text { or coexist with them }\end{array}$ & Views on what is seen in the mirror \\
\hline Views on perception (idrāk) & Views on senses (hawās) \\
\hline
\end{tabular}

As can be understood from the table above, subjects al-Ka'bi discussed in his Maqālāt under the lațif al-kalām heading seem to have a similar theme to those that al-Ash'arī included in his Maqālāt under the daqī al-kalām heading. What differs between al-Ka'bī and al-Ash'⿳ari is that al-Ka'bì starts his chapter with the question of whether the nonexistent can be considered a thing rather than the problem of the nature of objects. This question that is of both ontological and epistemological aspects, became, later on, one of the main questions of dispute among the mutakallimūn. It is also possible to find information in al-Ka'bī's Maqālāt, which are not available in al-Ash'arī's Maqālāt, on the ideas of some mutakallimūn, such as Abū al-Hudhayl and al-Nažzām, about the structure and the properties of bodies, motion, causality, the nature of space and time.

The other Maqālāt work we are going to examine belongs to Shaykh al-Mufìd (d. 413/1022). Similar to al-Ka'bī and al-Ash'arī, he also discussed the mutakallimūn' ideas related to physics and cosmology under the heading of lațif issues (bāb al-qawl fi al-lațîf min al-kaläm). ${ }^{51}$

\begin{tabular}{|c|c|}
\hline \multicolumn{2}{|c|}{$\begin{array}{c}\text { SOME HEADINGS FROM THE LAṬīF MIN AL-KALĀM CHAPTER } \\
\text { OF SHAYKH AL-MUFĪD'S AWĀ'IL AL-MAQĀLĀT }\end{array}$} \\
\hline Substances/atoms (jawāhir) & Quiddity (māhiyya) of the universe ('ālam) \\
\hline $\begin{array}{l}\text { Are substances/atoms homogeneous } \\
\text { (mutajānis) or different (ihtilāf) from each } \\
\text { other? }\end{array}$ & Celestial sphere (falak) \\
\hline $\begin{array}{l}\text { Do substances/atoms have surface (masāha) } \\
\text { and magnitudes (aqdār)in themselves? }\end{array}$ & Motion of the celestial sphere \\
\hline $\begin{array}{l}\text { Place (hayyiz) of substances/atoms and } \\
\text { accidents of location ( } a k w a \bar{n})\end{array}$ & $\begin{array}{l}\text { Earth and its shape; is the earth moving or at } \\
\text { rest? }\end{array}$ \\
\hline $\begin{array}{l}\text { Substances/atoms and their concomitants: } \\
\text { accidents }\end{array}$ & $\operatorname{Void}\left(\right.$ khalä) and fullness $\left(\right.$ mal $\left.\vec{a}^{3}\right)$ \\
\hline
\end{tabular}

${ }^{51}$ al-Shaykh al-Mufĩd, Awāil al-Maqālāt, ed. Ibrāhim al-Anșārī (Mashad: el-Mưtamar al-`Ālam li Alfiyyah al-Shaykh alMufīd, 1413/2000), 95. 
Mehmet BULGEN (trans. Mehmet BULGEN)

\begin{tabular}{|c|c|}
\hline Persistence $\left(b a q \bar{a}^{\prime}\right)$ of substances/atoms & Place (makān) \\
\hline Do substances/atoms need a place (makān)? & Time (zamān) and moment (waqt) \\
\hline Bodies (ajsām) & Natures $\left(\operatorname{tab} \bar{a}^{c} i\right)$ \\
\hline Accidents ( $\left.a^{c} r a \bar{d} d\right)$ & $\begin{array}{l}\left.\text { Composition of bodies out of natures ( } \operatorname{tab} \bar{a}^{c} i\right) \\
\text { and their conversion into matter ('unșūr) and } \\
\text { usțuqus }\end{array}$ \\
\hline $\begin{array}{l}\text { Reversion (qalb) of accidents and their re- } \\
\text { creation (i'āda) }\end{array}$ & Will and its necessity \\
\hline Non-existent $\left(m a^{c} d \bar{u} m\right)$ & $\begin{array}{l}\text { Engenderment/secondary causation } \\
\text { (tawallud) }\end{array}$ \\
\hline $\begin{array}{l}\text { Difference between what is necessitated } \\
\text { (mūjab) and what is engendered (mutawallid) }\end{array}$ & $\begin{array}{l}\text { Types of generative (muwallid) and } \\
\text { engendered (mutawallid) acts. }\end{array}$ \\
\hline
\end{tabular}

As can be seen from the table, the headings of the latif al-kaläm chapter of Shaykh al-Mufïd's Maqālāt are largely similar to the issues that al-Ash'arī and al-Ka'bì dealt with under the daqīq and latiif chapters respectively. The difference is that, besides void, Shaykh al-Mufid included issues such as falak and its motion, as well.

Considering all three Maqālāt works together, it appears that, from the end of the $8^{\text {th }}$ century to the $9^{\text {th }}$ century, theologians were intensely concerned with philosophical and scientific issues and mostly treated them under the title of daqiq and latif issues. Also, the richness of the discussions held on physics-related issues and the participation of many mutakallimūn in these discussions show the emergence of a creative environment regarding the structure of the universe, matter and its properties. This assertion necessitates pursuing the origins of cosmological theories particularly atomism- maintained by the mutakallimūn in creative and authentic inner processes of disputation of that period of kaläm instead of external sources. The fact that the mutakallimūn developed a type of atomism unprecedented in other civilizations confirms this assertion.

On the other side, when looking at the books that Ibn Nadīm assigned to the mutakallimūn, we encounter a situation similar to that of Maqālät works. In his book, Ibn Nadīm ascribed various books written on particular issues of physics and cosmology to Hishām b. al-Ḥakam, Ḍirār b. 'Amr, Ḥafș al-Fard (d. 195/810), Abū Bakr al-Așamm, Bishr b. al-Mu'tamir (d. 210/825), Ja'fer b. Ḥarb, Mu'ammar b. 'Abbād, Abū al-Hudhayl al-'Allāf, Ḥusayn al-Najjār (d. 220-230/835-845), Ibrāhīm b. al-Sayyār al-Naz̧zām, and many more mutakallimūn. The scientific and philosophical books that Ibn al-Nadim attributed in his al-Fihrist to the $9^{\text {th }}$ and $10^{\text {th }}$-century mutakallimūn can be listed in chronological order as follows: ${ }^{.2}$

52 Alnoor Dhanani organized these books Ibn al-Nadim attributed to mutakallimūn under three headings as follows: Books written by mutakallimūn exclusively on certain physics subjects, Refutations of mutakallimūn against each other on various issues of cosmology, and Cosmology-oriented books written by mutakallimūn against different religions and thought systems. Kalām and Hellenistic Cosmology, 40. 
Hishām b. al-Hakam (d. 179/795): Kitāb al-Radd 'alā așhāb al-țabā'ic (The refutation of the Naturalists), Kitāb 'alā Aristutālīs fì al-tawhīd (Against Aristotle on tawhīd), Kitāb al-Radd 'alā al-zanādika (The refutation of the Zanādika), Kitāb al-Radd 'alā așhāb al-ithnayn (The refutation of the Dualists). ${ }^{53}$

Dirār b. 'Amr (d. 200/815 [?]): Kitāb Ikhtilāf al-ajzā' (On difference of the parts), Kitāb al-Dalāla 'alā hadath al-ashyā' (The Argument on createdness of the things), Kitāb al-Radd 'alā Aristutālīs fi al-jawāhir wal-a'rāạd (The refutation of Aristotle on substances and accidents), Kitāb al-Radd 'alā așhāb al-țabāi' (The refutation of the Naturalists); $;^{54}$

Abū al-Hudhayl al-'Allāf: Kitāb al-Jawāhir wal-a'rāạ (On substances and accidents), Kitāb al-Masā'il fì alharakāt wa ghayrihāa (The questions on motion and other accidents) and Kitāb al-Harakāt (On motion), Kitābu Tathbit al-a'rāẹ (The demonstration of accidents), Kitāb fí al-Șawt mā huwa (On sound, what is it), Kitāb al-Insān mā huwa (On human, what is it), Kitāb al-Tawlìd 'alā al-Nazzā̄m (Against al-Nażā̄m on

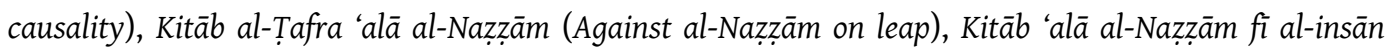
(Against al-Nazzā̄m on human), Kitāb 'alā al-sūfistā̄iyya (Against the Sophists), Kitāb 'alā al-majūs (Against Zoroastrians) ${ }^{55}$

al-Nažzām: Kitāb al-Juz' (On atom), Kitāb al-Tawallud (On causality), Kitāb al-Ṭafra (On leap); Kitāb alMudākhala (On al-mudākhala), Kitāb al-Harakāt (On motion), Kitāb al-Jawāhir wa al-árāẹ (On substances and accidents), Kitāb al-Insān (On human), Kitāb al-ma'nā 'alā Mu'ammar (Against Mu'ammar on alma'nā), Kitāb 'alā așhāb al-hayūlā (Against the Proponents of hyle), Kitāb al-Radd 'alā al-dahriyya (The refutation of the Dahriyya), Kitāb al-Radd 'alā așhāb al-ithnayn (The refutation of the Dualists):;6

Mu'ammer b. 'Abbād (d. 215/830): Kitāb al-Juz' alladhī lā yatajazza' (On the indivisible particle), al-Kawl bi al-al-a'rāẹ wa al-jawāhir (On substances and accidents), Kitāb 'illal al-karastūn wa al-mir'a (On balances and mirrors), ${ }^{57}$ Kitāb tathbit dalāla al-a'rāạ (The demonstration of accidents), Kitāb ithbāt al-juz' alladhì lā yatajazza' (The demonstration of the indivisible particle) $;^{58}$

Abū Bakr al-Așamm (d. 200/816): Kitāb al-Harakāt (On motion), ${ }^{59}$ Kitāb al-Radd 'alā al-dahriyya (The refutation of the Dahriyya); ${ }^{60}$

Hishām al-Fuwātī (d. 218/833): Kitāb al-Radd 'alā al-Așamm fī nafy al-ḥarakāt (Against al-Așamm on refutation of motion); ${ }^{61}$

Bishr b. Mu'tamir: Kitāb al-Tawallud 'alā al-Nazzām (Against al-Nazzām on causality);

Ja'far b. Ḥarb (d. 236/850): Kitāb al-Radd 'alā așhāb al-țabā'ic (The refutation of the Naturalists); ${ }^{62}$

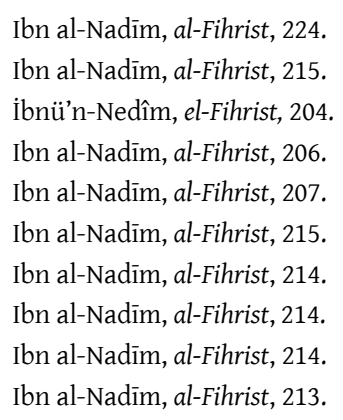


Abū Hāshim: Kitāb al-Naqd 'alā Aristutālīs fì al-kawn wa al-fasād (The critique against Aristotle on generation and corruption), Kitāb al-Ṭabā' $i^{c}$ wa al-naqd 'alā al-qā'ilīn bihā (On natures and the critique against their proponents). ${ }^{63}$

As is seen, the books that Ibn al-Nadīm reported clearly show that the mutakallimūn's interest in physics-related issues cannot be limited to a few names such as al-Naẓzām and al-Jāhiz, but this was a field of study to which theologians from all different groups actively contributed. In addition, it is noticed that the scholars of kalām not only contented themselves with writing books criticizing each other and other thought systems but also wrote to explain certain philosophical and scientific matters, such as the nature of knowledge, the structure of objects, substance, accident, motion, and causality.

On the other hand, Ibn al-Nadīm's al-Fihrist, and al-Ash'arī's and al-Ka'bī's Maqālāts give some hints about the beginning of philosophical and scientific discussions in kalām, because in these books, no physics-related ideas or scientific books were attributed to the scholars known as the first founders of kalām, such as Wāṣil b. 'Ațā' and 'Amr b. 'Ubayd. ${ }^{64}$ However, in the generation of Hishām b. al-Ḥakam, Dirār b. 'Amr and Abū al-Hudhayl al-'Allāf, a great number of ideas ${ }^{65}$ and books ${ }^{66}$ related to physics and cosmology were attributed to these scholars. The striking point here is that scholars such as Hishām and Dirār b. 'Amr lived even before al-Kindī, who is considered the first Muslim philosopher, and prior to the transmission of Greek philosophical works in the Muslim world. Some mutakallimūn' writing books ${ }^{67}$ criticizing Aristotle prior to the presence of the Muslim philosophers, like al-Kindī, indicates that they knew about Greek philosophers' ideas well enough to criticize them. ${ }^{68}$ This is of great importance in revealing the existence of the philosophical and scientific debates among the mutakallimūn before al-Kindi. ${ }^{69}$

It is also possible to demonstrate which philosophical and scientific issues that the mutakallimūn dealt with under the title of latif and daqiq matters through the example of Ibn Mattawayh's book called al-Tadhkira fi ahkām al-jawāhir wa al-al-a'rād (On the Properties of Substances/Atoms and Accidents). The value of this book arises from the fact that it is dedicated to the discussions on substances and accidents. Additionally, the other title of this book, Tadhkira fì lațif al-kalām, gives another evidence to the fact that the mutakallimūn examined physics and cosmology-related issues, such as substances and accidents, under the title of latîif al-kalām.

Ibn Mattawayh started Tadhkira fi latîf al-kalām with a classification about the objects of knowledge (malumāt) ${ }^{70}$ He classifies the objects of knowledge into two parts as mawjūd and $m a^{c} d \bar{u} m$. Mawjūd

63 Ibn al-Nadīm, al-Fihrist, 236 etc.

64 Ibn al-Nadim, al-Fihrist, 202.

65 al-Ash'arī, Maqālāt, 260.

66 Ibn al-Nadīm, al-Fihrist, 204, 224.

67 For instance, Hishām ibn Hakam's Kitāb 'alā Aristotālīs fi al-tawhīd, which he wrote on tawhìd against Aristotle; Dirār b. 'Amr's Kitāb al-Radd 'alā Aristotālīs fi al-jawāhir wa al-a'rāz, which he wrote on atoms and accidents against Aristotle. See. Ibn al-Nadīm, al-Fihrist, 204, 224.

68 For a noteworthy analysis on this, see. Dhanani, Kalam and Hellenistic Cosmology, 112-13.

69 Sayyed Husayn Nasr stated that those who first discussed issues such as the structure of bodies, motion, and causality in Islamic thought were the mutakallimūn.

$70 \quad$ Ibn Mattawayh, 2009: 1/6; for similar classification see Al-Bāqillānī, 1987: 34. 
means existent, while macdūm means non-existent. Again, in his opinion, all existents are also divided into two parts: qadīm (eternal) and hādith (temporally originated). Having divided existents into two as qadim and hādith, Ibn Mattawayh proceeds to divide all originated things into two: Substance/atom (jawhar) and accident ('arad) that inheres/occurs in substances. In this division, substance corresponds to a space-occupying object (mutahayyiz) when it exists, while accident refers to the thing not occupying space and not being able to exist by itself. According to the Ibn Mattawayh, all substances are a single genus (mutajānis); whereas accidents are of different types, such as colors, taste, smells, heat, cold, dryness, humidness, and spatial occurrences (akwān) like motion, rest, composition and separation, impetus/inclination/force (itimād), pain, voice, life, power, desire, hatred, will, dislike, belief, supposition, reasoning, and annihilation. ${ }^{71}$

One of the noteworthy parts of Ibn Mattawayh's exposition is his inclusion of the terms, such as qadim, hädith, jawhar, and 'arad, within the group of known things (ma'lumāt) in the most general sense. It shows that the mutakallimūn treated equally both God and the universe in terms of being objects of knowledge. ${ }^{72}$ The reducing of the universe into bodies, substances and accidents, and subsequently the reaching to the concepts of "qadim" and "muhdath" through them are characteristics of this exposition. Beyond this, the mutakallimūn's division of existents into two, as God and the universe, reveals their attempt to use the theory of jawhar-'arad in order to explain everything existent other than God. Therefore, it could be said that for Ibn Mattwayh, kalām was not a discipline dealing only with God or the properties of material objects but also a universal discipline examining all existents. ${ }^{73}$

It would be beneficial to look closely at this book of Ibn Mattwayh to see in which contexts the mutakallimūn used the concepts of substance/atom and accident at that time. Ibn Mattawayh started his book with a chapter on the parts of accidents and then a chapter on substances comes. The subjects he discussed in the chapter on substances can be listed as follows: ${ }^{74}$

\begin{tabular}{|l|l|}
\hline \multicolumn{3}{|c|}{$\begin{array}{l}\text { SOME HEADINGS FROM THE SUBSTANCE/ATOM (JAWHAR) } \\
\text { CHAPTER OF IBN MATTWAYH'S AL-TADHKIRA }\end{array}$} \\
\hline $\begin{array}{l}\text { Bodies (ajsām) do not consist of the } \\
\text { combination of accidents (árāa })\end{array}$ & Bodies do not need a place (makān) (to exist) \\
\hline $\begin{array}{l}\text { Substances/atoms (jawāhir) are perceived } \\
\text { (mudrak) through seeing and touching }\end{array}$ & $\begin{array}{l}\text { On qualities (sifāt) of the substance/atom } \\
\text { (jawhar) }\end{array}$ \\
\hline
\end{tabular}

Ibn Mattawayh, 2009: 1/6; also see Baghdādī, 1928:35-36; Al-Nasafī, 2004: 1/62-63.

72 Knowledge's relation to non-existent ( $m a^{c} d \bar{u} m$ ) according to the mutakallimūn led to the debate whether or not nonexistent is a thing in terms of being an object of knowledge. According to the Basrian Mu'tazila, because substance and accident are objects of God's knowledge, they should have an essential quality that distinguishes them from each other even when they are non-existent. However, the Baghdadī Mu'tazila and Ash'arites did not accept such a claim on the ground that it would remove substances and accidents from being subject to God's will in terms of having their own essential qualities.

73 It is repeatedly stated by many mutakallimūn that kalām is a universal discipline (al-'ilm al-kullī). Imām al-Ghazālī is one of them. See Imām al-Ghazālī, Al-Mustașfā min 'ilm al-uṣul al-Ghazālī, ed. Ḥamza bin Zuhair Hafiz. Vol.1. (alMadīna al-Munawwara: al-Jama'a al-Islāmiyya), 12.

74 The headings belongs to Daniel Gimaret, who edited Ibn Mattawayh's al-Tadhkira. Cairo edition is used. (Cairo: alMa'hat al-Fransī, 2009). 


\begin{tabular}{|c|c|}
\hline $\begin{array}{l}\text { stance/atom (jawhar) is only a state } \\
\text { nce }\end{array}$ & $\begin{array}{l}\text { Occupying space (tahayyuz) and existence } \\
(\text { wujūd) are different qualities of } \\
\text { substance/atom (jawhar) }\end{array}$ \\
\hline $\begin{array}{l}\text { /atom has the state of being in a } \\
\text { jihat) }\end{array}$ & $\begin{array}{l}\text { Substances do not have a state when non- } \\
\text { existent }\end{array}$ \\
\hline $\begin{array}{l}\text { no increase in the quality of being } \\
\text { oo }\end{array}$ & $\begin{array}{l}\text { An increase in the qualities of } \\
\text { substance/atom except existing in a direction } \\
\text { is not possible }\end{array}$ \\
\hline $\begin{array}{l}m \text { is substance when non- } \\
\text { when existent }\end{array}$ & $\begin{array}{l}\text { Rebuttal of those who claim that } \\
\text { substance/atom is not substance when non- } \\
\text { existent }\end{array}$ \\
\hline$n$ does not occupy space when & $\begin{array}{l}\text { occupation for substance/atom does } \\
\text { appen through an agent }\end{array}$ \\
\hline $\begin{array}{l}\text { /atoms are created due to the } \\
\text { ty of them being devoid of spatial } \\
\text { s (akwān) }\end{array}$ & $\begin{array}{l}\text { r the temporality } \\
\text { m) }\end{array}$ \\
\hline (jāiz) for the infinite $(m \bar{a} l \bar{a}$ & $\begin{array}{l}\text { ent that created things } \\
\text { ig }\end{array}$ \\
\hline $\begin{array}{l}\text { hose who deny the temporality of } \\
\text { e (huduth al-'älam) and responses to } \\
\text { s }\end{array}$ & $\begin{array}{l}y \text { of proving the createdness of } \\
\text { ithout relying on the createdness of }\end{array}$ \\
\hline $\begin{array}{l}\text { use for substance/atom not being } \\
\text { st in two directions (jihatayn) at one }\end{array}$ & $\begin{array}{l}\text { e does not generate something just } \\
\text { t generated out of something }\end{array}$ \\
\hline abstances/atoms to exist & $\begin{array}{l}\text { Jaz̧āām's idea of } \\
\text { ul) }\end{array}$ \\
\hline $\begin{array}{l}\text { On } \\
\text { sub }\end{array}$ & $\begin{array}{l}\text { of two substances } \\
\text { en them due to the } \\
\text { e }\end{array}$ \\
\hline $\begin{array}{l}\text { Statement on the possibility of } \\
\text { substance/atom being devoid of all accidents } \\
\text { except for the accident of location (kawn) }\end{array}$ & $\begin{array}{l}\text { Impossibility of making a definitive judgment } \\
\text { regarding the absence of color in the body }\end{array}$ \\
\hline Homogeneity (mutamāthil) of all substances & e/atom \\
\hline $\begin{array}{l}\text { Doubts of those who deny the existence of } \\
\text { [indivisible] part }\left(j u z^{\prime}\right) \text { and responses to these } \\
\text { doubts }\end{array}$ & 2000 \\
\hline $\begin{array}{l}\text { Rejection of the one who says that it is } \\
\text { impossible for air to turn into water. }\end{array}$ & $\begin{array}{l}\text { On the annihilation }\left(f a n \bar{a}^{\prime}\right) \text { and } r \\
\left(i^{(} \bar{a} d a\right) \text { of substances/atoms }\end{array}$ \\
\hline
\end{tabular}


After dealing with the substance in detail, he analyzed accidents under the titles of colors, taste, smells, heat, cold, dryness, humidness, and spatial occurrence (akwān) like motion, rest, composition, separation, inclination/force (itimād), pain, voice, life, power, desire, hatred, will, dislike, belief, supposition, reasoning. ${ }^{75}$ It is understood from Ibn Mattawayh's explanations that in the $9^{\text {th }}$ and $10^{\text {th }}$ centuries, the Muctazila separated into two schools, the Basrian and the Baghdadī, and they argued for different opinions about daqia or latîf matters such as the properties of the atom, types of accidents, void, the nature of motion and causality, even though they all adopted atomism. ${ }^{76}$

When we consider Ibn Mattawayh's book of al-Tadhkira together with the other books we have examined before, we reach the conclusion that the mutakallimūn, under the title of daqiq or lațif alkaläm, largely focused on two controversial areas. ${ }^{77}$

a. The Key Components of the Universe: In the classical period, one of the topics frequently discussed by the mutakallimūn under the title of daqiq matters was the fundamental elements of the universe. It is seen that in the $9^{\text {th }}$ century, the mutakallimün, gathered around three different opinions on the structure of bodies in the universe. The group led by Dirār b. 'Amr, Ḥusayn al-

75 Ibn Mattawayh, in this book, dealt with accidents in a very detailed way, just as he did about substance/atom. For example, it is possible to title the subject of colors as follows: On the Reality of Color, On the Impossibility of Perceiving an Object without Perceiving Its Color, On Color not Being an Object or a Quality of an Object, On the Number of the Basic Colors being Five: Black, White, Red, Green, and Yellow, On the Possibility of Adding on These Types of Colors, On the Homogeneity of Each Color Type, On the Possibility of Two Homogenous Accidents Existing in The Same Place, On the Possibility of the Contrast between Two Colors Being in Two Aspects: Either in Reality or in Genus, On the Case of Elimination of One Contrary the Other Its Non-existence not by means of a Cause but a Condition, Impossibility of Color Existing without Being in a Place, On the Impossibility of Seeing Colors in case of Them Existing without Being in a Place, On the Possibility of Existence of a Color Inherent in a Place Only in that Place, On the Impossibility of the Transference of Accidents, On the Impossibility of Accidents' Inherence in Accidents, On Color's Need only for a Place not for a Structure and Two Places, On Establishing the Createdness of Colors and Other Accidents], On Color Being Exclusive to God's Power not Ours, On Color not Being Originated from Others and Not Originating Others, [Perpetuity of Colors, On the Proof about the Perpetuity of Colors and Stating the Answer to These Proofs. see al-Tadhkira, 126-153.

76 Another Mu'tazilī mutakallim Abū Rashīd al-Nīsābūrī, a contemporary of Ibn Mattwayh, dealt with the disagreements between the Basrian and Baghdadī Mútazila in a detailed way in the center of substance and accident. For example, some of the conflicts about the Basrian and Baghdadī schools are as follows: On the Equality (tamäthul) of Substances/atoms, On Substance/Atom Being Substance/Atom in case of its Non-existence, On the Possibility of Two Substances/Atoms Being Separated (Muftariq) without a Third Substance/Atom in between, On Accidents Being Gathered in a Place, On the Existence of a Hidden (Kämin) Fire in Stone and Wood, On the Conversion of Air into Water, On Each Substances/Atoms (jawhar al-fard) Having a Specific Location (masāha), On the Possibility of Separation of Substances from Each Other, On Whether The Direction of Part Being Different from Part or Direction Belonging Part], The Existence of Substance Only in case of Occupying Space and This Happening only It Being in a Direction, On Whether or not Atom Being Individuated (Munfarid) due to a Cause, On the Possibility of Substance Being Devoid of All Accidents except the Accident of Location (Kawn), On the Impossibility of Substance Being Perpetual due to a Cause, On the Impossibility of Occurrence (Țāri') of Substance due to a Cause at the Time of Its Existence, On the Annihilation of Substance with Its Contrary, On the Impossibility of Some Substances Being Perishable and Some Substances Being Persistent, On the Possibility of Placing an Atom (juz') on Two Atoms' Conjunction Point (Mawzi al-Ittisāl), On Whether Earth Being Spherical or not." After relating debates between the Basrian and Baghdadī schools as mentioned, Nīsābūrī also presented disagreements on accidents in detail. alNīsābūrī, al-Masā’il fi al-khilāf bayn al-basriyyīn wa al-Baghdādiyyīn, 28-104.

77 Alnoor Dhanani, Kalām and Hellenistic Cosmology, 40. 
Najjār, and Hafș al-Fard claimed that objects are constituted through the aggregation of some accidents, such as heat and cold. Hishām b. al-Hakam and al-Așamm , on the other hand, maintained that the universe is entirely made up of the bodies. Thirdly, Abū Hudhayl and Mu'ammar argued that the universe is comprised of bodies and accidents, and bodies are comprised of atoms. al-Nazzām, however, opposing the atomism, claimed that the universe is wholly made up of bodies except for motion, which is an accident. Thus, we can put al-Naz̧zām in the second group.

Among these three opinions, the atomist one holding that the universe is made up of bodies that are constituted of atoms and accidents, became later on the dominant opinion among the mutakallimūn. However, atomist scholars could not come to an agreement on issues, such as the definition of body, substance, and accident, whether or not atoms can exist separated from each other, whether or not atoms have shape, size and weight, the number of atoms required for the formation of the smallest body, and which accidents atoms can bear on their own. They intensely engaged in discussions about whether or not bodies interpenetrate each other (mudākhala), whether or not bodies are the same genus (mutajānis/mutamāthil), what causes the distinction in bodies, motion-rest, composition-separation (akwān), heat-cold, dryness-humidness, colour, the nature of sound and light, and the occurrence of hearing and seeing as well. ${ }^{78}$

b. Functioning of the Universe and Causality: Another subject that the mutakallimūn are largely concerned with is how events in the universe function. In this context, the following issues were discussed: Whether or not objects have nature ( $(\operatorname{tab} \bar{a}(i)$, causality, secondary causation (tawlid), how the continuity of objects is ensured, motion-rest, and agregation-separation. Even though the mutakallimūn are generally claimed to refuse the necessary natural causality, they developed theories, such as custom ('āda), lantency (kumūn) - appearance (zuhür), meaning (ma'nā), conjunction (iqtirān), impetus or force ('itimād), and tawlìd in order to explain the systematic functioning of the universe. ${ }^{79}$ Indeed, when the debates of the Basrian and Baghdadi schools of the Mu'tazila are considered, it appears that they supported different opinions on the properties of objects and causality. The Basrian school maintained that the relationship between cause and effect results from the custom ('āda) set by God. According to them, if God wills, He can keep a heavy rock from falling and hinder the result of burning despite the existence of cotton and fire; he can even create an animal from the sperm of a human. However, the Mu'tazilites of Baghdad, believing that God's power cannot be against the nature of objects, argued that God could not create barley out of wheat. Similarly, in their opinion, without the existence of support, it is not possible for a heavy object to remain in the air and for fire not to burn cotton..$^{80}$ On causality, the Ash'arites and Māturīdites mostly rejected inherent natures (taba $\left.\bar{a}^{c} i\right)$, the theory of secondary causation (tawlid), and adopted an 'āda-based approach. ${ }^{81}$

al-Khayyāț, Kitāb al-Intișār, 15; al-Ash`arī, Maqālāt, 74.

Ahmet Mekin Kandemir, Mu’tezili Düşüncede Tabiat ve Nedensellik (İstanbul: Endülüs, 2019), 253.

Shaykh al-Mufīd, Awāil al-Maqālāt, 129-130; Nīsābūrī, al-Masāill, 133; Ibn Mattawayh, al-Tadhkira, 1/323; cf. Metin Yıldız, İbn Metteveyh'in Kozmoloji Anlayışı, 74-75.

81 According to what Ibn Fūrak reported, al-Ash'arī maintained that upward movement of fire and downward movement of the stone does not due to a nature necessitating these movements or a cause producing them (muwallid). Similarly, al-Ash'arī argued for the possibility of God removing coldness and wetness from water and 
Without a doubt, the scientific and philosophical issues that the mutakallimūn discussed do not consist of only the key elements of the universe and causality. They also largely engaged in discussions on ontological and epistemological issues, such as existent (mawjūd), non-existence ( $m \bar{a}^{c} d \bar{u} m$ ), essence (zāt) attribute (sıfat), the possibility of knowledge, its definition, types, and sources. In addition, they also debated over such matters as the nature of humans, their actions, their physiological and psychological characteristics, how human perception and knowledge occur, and whether he has free will or not. However, the mutakallimūn's views on human conform to the two principles mentioned above. Whichever views a mutakallim maintains on the key elements of the universe and causality, his ideas on humans becomes compatible with it. For instance, Dirār b. 'Amr, claiming the constitution of the universe to be of accidents, stated that humans are also made up of accidents such as colour, taste, smell, and power, and that there is no substance in humans. ${ }^{82}$ As for al-Ash'arī, who asserts that the universe consists of substances and accidents claimed that the soul is a delicate body belonging to the genus of breath, and considered such elements as life, will, and knowledge to be accidents. ${ }^{83}$ al-Nazzāam, who maintained that accidents apart from motion are bodies, considered the soul to be a delicate body and explained humans' liveliness based on it. In addition, the scholars of kaläm also discussed whether or not humans are agents and creators of their actions based on the continuity of accidents, which is a cosmological matter.

Another noteworthy point to be mentioned about the mutakallimūn's discussions on physics and cosmology-related matters is the significant impact of the Arabic language on kalām debates. Most mutakallimūn took the lexical meaning to determine the denotations of the key terms such as the universe, object, substance, accident, motion, and rest. This situation, which implies that Arabic is not only a means of communication but a carrier of a worldview for the mutakallimūn, contributed to the uniqueness and locality of the physical theories of the mutakallimūn. ${ }^{84}$

Consequently, upon evaluating al-Ash`arī's, al-Ka'bī's and Shaykh al-Mufĩd's Maqālāt, Ibn alNadim's al-Fihrist and Ibn al-Mattawayh's al-Tadhkira together, it is possible to reach to the

creating heat and dryness in it. See. Ibn Fūrak, Mujarrad, 132. Again according to Ibn Fūrak's report, al-Ash'arī was claiming that incidents, such as drunkenness after drinking wine, satiety after eating, satisfaction after drinking water, wellness after taking medication, ignition after contact with fire, falling of stone after being thrown into the air, do not originate from causal factors $\left(m a^{i} n \bar{a}\right)$ that are necessitated by nature or from engendered causes that produce them. In Imam al-Ash'ari’s opinion, all of these have happened by God's choice. God has created them with a custom that takes place in the creation (ihdāth) of things. See. Ibn Fūrak, Mujarrad, 283; also see. ibid., 134; Juwaynī, al-Shāmil fì ușūl al-dīn. Beirut, 1999, 154-5.

82 al-Ash'arī, Maqālāt, 260.

83 For instance, Ibn Fūrak stated in his book under the title "Explanation of al-Ash'arī's View on the Soul, Life, and Issues Related to Them" as follows: al-Ash'arī was saying: Our life is an accident and originated (muhdath)... When it comes to the soul (rūh), according to al-Ash'arī, it is wind (rīh). It is a delicate object and circulates in the hollows of man's limbs. However, humans become alive by means of life, not with the soul. al-Ash'ari was saying: Survival of body with the soul takes place in the form of custom. It is similar to the survival of the body with nourishment, food, and drinking. Accordingly, just as it is impossible for humans to live without food, it is also impossible for them to live without the soul. Because a living being needs food and the soul in terms of being alive ... al-Ash'ari considered the soul to be similar to the wind. In fact, the soul per se meant wind. On this issue, see. Ibn Fūrak, Mujarrad, 267.

84 See. Mehmet Bulğen, “The Power of Language in the Classical Period of Kalam”, Nazariyat 5/1 (May 2019), 37-82. 
following drastic conclusion: The mutakallimūn largely interested in philosophical and scientific issues related to physics and cosmology in the classical period starting from the end of $7^{\text {th }}$ century to the $12^{\text {th }}$ century. Especially the $9^{\text {th }}$ century is a period when the mutakallimūn' interest in philosophical and scientific issues was highly intense. Even though the mutakallimūn's interest in these types of matters has to do with the need to advocate Islam against other religions and thought systems, such as dualists, naturalists, Peripatetics, materialists, sceptics, and heretics, it would be wrong to describe their engagement in physics and cosmology-related matters as mere apologetic or a means to reject opposing views. As is understood from al-Ash'arî’s Maqālāt and Ibn al-Nadim's al-Fihrist, the mutakallimūn have not only written books against other thought systems or condemned them, but they also developed alternative terms and theories on the structure of bodies, their functioning and the nature of human. Moreover, the mutakallimūn penned books ${ }^{85}$ solely with the purpose of explicating some physics matters without any theological context. This case indicates that some mutakallimūn' approaches to physics and cosmology were not merely based on religious concerns but also on being seekers of truth.

Lastly, it should be noted that the mutakallimūn's interest in the theory of knowledge and natural philosophy was not limited to the classical period but increasingly continued in the period after al-Ghazālī. For example, while only the fifth and the sixth chapters of 'Adud al-dīn al-îjì's (d. 756/1355) Mawāqif are related to the theological matters, the remaining parts contain epistemological, ontological and cosmological issues. ${ }^{86}$ Sa'd al-dīn al-Taftāzānī (d. 792/1390) referred to this situation by saying that, "It is almost impossible to differentiate kalām books from philosophy books except for the chapters of sam "iyyāt". ${ }^{87}$

\section{Conclusion}

In the present article, based on the extant kalām books, we have attempted to show that kalām's matters were divided into two main categories as daqiq or lațif al-kaläm and jalil al-kalām in the classical period of kaläm, between the $9^{\text {th }}$ and $11^{\text {th }}$ centuries. In this division, jalil matters correspond to revelation-based issues, on which the mutakallimūn had a consensus, such as the existence of God, His oneness, revelation, prophethood, and the hereafter. On the other hand,

85 Abū al-Hudhayl's Kitāb fi al-șawt mā huwa, which he wrote on the nature of sound, Mu'ammar ibn 'Abbād's (d. 215/830) Kitäbu 'ilal al-karastūn wa al-mir'at, which he wrote about balances and mirrors, can be given as examples of this. See. Ibn al-Nadīm, al-Fihrist, 204, 207.

86 In kalām, subjects related to epistemology, ontology, and cosmology have been named differently in different periods. While, in the classical period prior to Ghazzālī, the term "daqiq al-kalām" was more common, in the postclassical period, for example, 'Adud al-Dīn al-'َ̄jī discussed existence, unity, multiplicity, essence, causality under the title of "al-Umūr al-'Amma". See. 'Adud al-Dīn al-'̄ijì, al-Mawāqiffí 'ilm al-kalām, (Bairut: 'Ālam al-kutub, n.d.), 41. Izmirli Ismail Hakkı (d. 1868-1946), one of the late Ottoman mutakallimūn, in Yeni Ilm al-Kalām (The New Science of Kalām), named these types of subjects as 'the principles' (mabādi') and 'the means' (wasā'il) and stated that they are a means of substantiating and defending theological principles. According to Izmirli, while 'the issues' (masā $i l)$ and 'the aims' (maqāșid), which constitute the pillars of Islam and its final goals, always remains the same, mabādi' and wasä'il, which helps to explain and better understand them, is constantly renewed, and constantly change according to the age and conditions. Ismail Hakkı İzmirli, Yeni İlm-i Kelam, (Istanbul: Awqāf al-Islāmiyya Publishing, 1339-1341), 1/7-8. Also see. İlyas Çelebi, “Ortaya Çıkışından Günümüze Kelam İlminde "Konu” Problemi”, Marmara Üniversitesi Ilahiyat Fakültesi Dergisi, 28 (2005/1), 9.

87 Al-Taftāzānī, Sharh al-'Aqā̄id, (Beyrut: 2007), 55. 
matters included under the title of daqiq or latif mainly refer to physical and philosophical questions related to knowledge, ontology and the universe.

The reason why the mutakallimūn engaged in philosophical and scientific issues might seems, at first glance, to demonstrate and defend jalil issues, which are regarded as the principles of religion; however, their involvement in daqiq or latiif issues requires a further explanation other than just being apologetic. The is because the scholars of kalām interested in daqiq or latîf matters more than a typical scholar of religion. The classical sources that we have referred show that the mutakallimūn developed various comprehensive theories in order to solve the main problems of physics and cosmology. Moreover, the mutakallimūn did not only debate over physics-related issues among themselves or with opposing thought systems, but they also produced works in order to enlighten physics-related problems without any theological background. ${ }^{88}$ This shows that the mutakallimūn, et least some of them, engaged in philosophical and scientific issues as the seekers of truth, not just for apologetic purposes. Indeed, this holds great importance in terms of showing that the mutakallimūn's theological arguments on the existence of God have a considerable philosophical basis and that they were fed on the activity of exploring nature.

Here, we need to make a final point. The first engagement of the mutakallimūn in philosophical and scientific matters such as knowledge, existence, non-existence, body, substance, accident, void, motion, and causality dates back to the mid- $8^{\text {th }}$-century and coincides with a period when the translation activities led by philosophers like al-Kindi did not start yet in the Islamic world. Especially, the $9^{\text {th }}$ century corresponds to a period when the interest in philosophical matters related to knowledge, existence, and the universe reached its peak and flourished. In this century, the mutakallimün concerned themselves with matter and the universe and developed various theories and unique terms, in a rare way in the history of the world. However, they cannot be said to have received the credit they deserve in the academic research on the history of Islamic science and philosophy. The consideration of the mutakallimün as theologians in modern researches causes historians of science to overlook kalām books and therefore leads to the inability of properly explaining the emergence and development of philosophy and science in Islamic thought. Further researches that closely look at the $8^{\text {th }}$ and $9^{\text {th }}$ century kalām would help to recognize better the philosophical and scientific contributions of the mutakallimūn to the Islamic world in particular and the universal culture in general.

\section{Acknowledgements}

This article is the updated and substantially revised version of the previously published article in Turkish: Mehmet Bulğen, "Klasik Dönem Kelâmında Dakiku'l-Kelâmın Yeri ve Rolü", İslâm Araştırmaları Dergisi 33 (2015), 39-72. I want to thank Zeliha Uluyurt, Ertul Ortabas, Abdullah Yıldız and Emine Acar for their contribution to the translation of the article into English.

The author is on the editorial board of Kader. However, in this issue, in which the author's article was published, the editorial duties and authorizations of the author were suspended. Thus, the principle of double-blind refereeing was complied with.

$88 \quad$ Ibn al-Nadìm, al-Fihrist, 206. 


\section{Bibliography}

Anawati, Georges C.. "Kalām". Encyclopedia of Religion (2 ${ }^{\text {nd }}$ edition). ed. Lindsay Jones. USA: Macmillan, 2005.

Al-Ash`arī, Abū al-Ḥasan. Maqālāt al-Islāmiyyīn wa ikhtilāf al-mușallīn. ed. Hellmut Ritter. Wiesbaden:1963.

Al-Baghdādī, 'Abd al-Qāhir. Ușūl al-Dīn. Beirut: Dār al-Kutub al-'Ilmiyya, 1981.

Bulğen, Mehmet. “Klasik Dönem Kelâmında Dakiku'l-Kelâmın Yeri ve Rolü”. İslâm Araştırmaları Dergisi 33 (2015), 39-72.

Bulğen, Mehmet. “The Power of Language in the Classical Period of Kalam”. Nazariyat 5/1 (May 2019), 37-82.

Çelebi, İlyas. “Ortaya Çıkışından Günümüze Kelam İlminde “Konu” Problemi”. Marmara Üniversitesi İlahiyat Fakültesi Dergisi. 28 (2005/1).

Dhanani, Alnoor. "Kalām and Hellenistic Cosmology: Minimal Parts in Basrian Mu'tazili Atomism”. (Dissertation, Harvard University, 1991).

Dhanani, Alnoor. "Problems in Eleventh-Century Kalām Physics". Bulletin of the Royal Institute for Inter-Faith Studies 4/1 (Spring/Summer 2002).

Dhanani, Alnoor. The Physical Theory of Kalām: Atoms, Space, and Void in Basrian Mu'tazili Cosmology. Leiden: Brill E. J. Brill, 1994.

al-Ghazālī, Abū Ḥāmid. Al-Mustașfā min 'ilm al-uṣul. ed. Ḥamza bin Zuhair Hafiz. Vol.1. Madina alMunawwara: al-Jama‘a al-Islāmiyya.

Gölcük, Şerafettin. "Hayyāt”. TDV İslām Ansiklopedisi (DİA).

Heinen, Anton M.. “Mutakallimūn and Mathematicians”, Der Islam 55/1 (1978), 57-73.

Ibn al-Murtaḍā, Aḥmad b. Yahyyā. Bāb Dhikr al-Mu'tazila min Kitāb al-Munya wa al-amal. ed. Thomas Walker Arnold. Leipzig, 1902.

Ibn al-Murtaḍ̄ā, Ahmad b. Yahyyā. Kitāb Ṭabaqāt al-Mu'tazila. ed. Susanna Diwald Wilzer. Beirut: Maktaba al-Hayāt, n.d..

Ibn al-Nadīm. al-Fihrist. ed. Riza Tajaddud. Tahran, 1971.

Ibn al-Wazīr. İthār al-haqq 'alā al-khalq. ed. Anū 'Abd al-Raḥmān Nabil Salah 'Abd al-Majīd Salīm. Samanud (Eygpt) Maktaba Ibn ‘Abbās, 2010.

Ibn al-Wazīr. Tarjīh asālib al-Qur'ān 'alā asālib al-Yūnān. Beirut: Dār al-Kutub al-'Ilmiyya, 1984.

Ibn Fūrak. Mujarrad maqālāt al-Shaykh Abī al-Hasan al-Ash'arī. ed. Daniel Gimaret. Beirut: Dār alMashriq, 1987.

Ibn Mattawayh. al-Tadhkira fī aḥkām al-jawāhir wa al-a'rāḍ. ed. Daniel Gimaret (Cairo: al-Ma'ha alFransī, 2009). 
İjīi, Aḍu al-dīn. al-Mawāaiffí 'ilm al-kalām. Beirut: A'lam al-kutub, n.d..

Izmirli Ismail Hakkı. Yeni Ilm-i Kelâm. Istanbul: Evkāf-1 Islāmiyye Matbaası, 1339-1341.

Al-Jāhị. Kitāb al-Hayawān. ed. Abd al-Salām Muhammad Hārūn (Beirut: Dār ihyā' al-turāth al'Arabī, 1388/1969).

Al-Jushamī, al-Ḥākim. Shharḥ al-'Uyūn (in Faḍlu al-i'tizāl wa Ṭabaqāt al-Mu'tazila), ed. Fuād Sayyid. Tunisia, 1393/1974.

Al-Juwaynī, Abū al-Ma'ālī. al-Burhān fi uṣūl al-figh. (ed. 'Abd al-'Azīm al-Dib) Doha: Jāmi'a Qatar, $1978,1 / 84$.

Al-Juwaynī, Abū al-Ma‘ālī. al-Shāmil fì uṣūl al-dīn. Beirut, 1999.

Al-Ka'bī, Abu'l-Qāsim al-Balkhī. Kitāb al-Maqālāt wa ma'ahu 'Uyūn al-masā’il wa al-jawābāt. ed. Hüseyin Hansu - Rājih Abdulhamīd Kurdī. Istanbul, Amman: KURAMER, Dār al-Fath 2018.

Kandemir, Ahmet Mekin. "The Hand Extending Beyond the Cosmos: Discussions on the Khalā' [Void] Between the Bașran and Baghdād Schools of Mu'tazila". Nazariyat 7/1 (May 2021), 1-36.

Kandemir, Ahmet Mekin. Mu’tezili Düşüncede Tabiat ve Nedensellik. İstanbul: Endülüs, 2019.

Al-Khayyāț, Abū al-Ḥusayn. Kitāb al-Intișār. ed. Albert Nasri Nader. Beirut, 1957.

Ma`n Ziyāda-Ridvān Sayyīd, al-Masā’il fì al-khilāf bayn al-basriyyīn wa al-Baghdādiyyīn (Abū Rashīd al-Nīsābūrī's foreword), Beirut, 1979.

Mcdermott, Martin J.. The Theology of al-Shaikh al-Mufid. Beirut, 1978.

Nasr, Sayyed Hossein. Islamic Philosophy from its Origin to the Present. (New York: State University of New York Press 2006), 123.

Qāḍī ‘Abd al-Jabbār. al-Majmū‘ fì al-Muhịt bil-taklîf. ed. J. J. Houben. Beirut: Dār al-Mashriq, 1986.

Qāọī 'Abd al-Jabbār. Faḍlu al-i'tizāl wa Ṭabaqāt al-Mu'tazila (in Faḍlu al-i'tizāl wa Ṭabaqāt alMu'tazila). ed. Fuād Seyyid (Tunus 1393/1974).

Sabra, A. I.. "Science and Philosophy in Medieval Islamic Theology: The Evidence of the Fourteenth Century”. Zeitschrift für Geschichte der Arabisch-Islamischen Wissenschaften, no: IX, 1994.

Shaykh al-Mufîd. Awā̉il al-maqālāt. ed. Mahdī Muhaqqiq. (Tahran: Dānishgāh-e Tahrān, 1372/1993).

Shaykh al-Mufīd. Awāil al-Maqālāt. ed. Ibrāhim al-Anșāini Mashad: al-Mu'tamar al-cālam li Alfiyyah Al-Shaykh al-Mufid, 1413/2000

Al-Taftāzānī. Sharh al-'Aqā’id. Beyrut, 2007.

Al-Tāī, Muhammad Bāsil. "The Scienti-fic Value of Daqîq al-Kalām”. Islamic Thought and Scientific Creativity V/2, (1994), 7-18.

Al-Tawhīdī, Abū Ḥayyān. Kitāb al-Adab wa al-inshā fỉ al-șadaqa wa al-șadīq. Qairo: 1323/1905. 
Van Ess, Josef. "Ebû İshāk en-Nazzām Örneği Üzerinden Kelâm-Bilim İlişkisi”. trns. Mehmet Bulğen. Marmara Üniversitesi îlăhiyat Fakültesi Dergisi 46 (2014).

Van Vloten, Gerlof. Ein arabischer Naturphilosoph im 9. Jahrhundert el-Dschāhiz. Stuttgart, 1918.

Watt, Montgomery. Free will and Predestination in Early Islam. London: Luzac \& Comany Ltd., 1948.

Yavuz, Yusuf Şevki. “Câhîz”. TDV İslâm Ansiklopedisi (DİA).

Yıldız, Metin. Kelam Kozmolojisi Mu’tezilenin Âlem Anlayışı. Istanbul: Endulus, 2020. 